\title{
The Impact of Wearable Technologies in Health Research: Scoping Review
}

Sophie Huhn ${ }^{1}$; Miriam Axt ${ }^{1}$, BA; Hanns-Christian Gunga ${ }^{2}$, Prof Dr; Martina Anna Maggioni ${ }^{2,3}$, PD, PhD; Stephen Munga $^{4}$, PhD; David Obor ${ }^{4}$, MSc; Ali Sié ${ }^{1,5}, \mathrm{PhD}$; Valentin Boudo ${ }^{5}$, MSc; Aditi Bunker ${ }^{1}$, Dr sc hum; Rainer Sauerborn ${ }^{1}$, Prof Dr; Till Bärnighausen ${ }^{1,6,7}$, Prof Dr; Sandra Barteit ${ }^{1}$, Dr sc hum

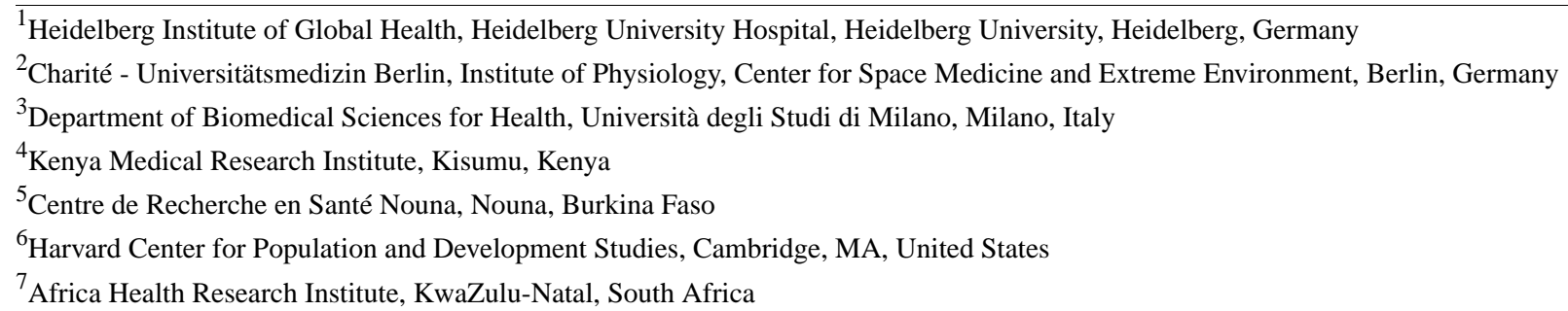

\section{Corresponding Author:}

Sophie Huhn

Heidelberg Institute of Global Health

Heidelberg University Hospital

Heidelberg University

Im Neuenheimer Feld 1303

Heidelberg, 69120

Germany

Phone: 4962215634030

Email: sophie.huhn@uni-heidelberg.de

\section{Abstract}

Background: Wearable devices hold great promise, particularly for data generation for cutting-edge health research, and their demand has risen substantially in recent years. However, there is a shortage of aggregated insights into how wearables have been used in health research.

Objective: In this review, we aim to broadly overview and categorize the current research conducted with affordable wearable devices for health research.

Methods: We performed a scoping review to understand the use of affordable, consumer-grade wearables for health research from a population health perspective using the PRISMA-ScR (Preferred Reporting Items for Systematic Reviews and Meta-Analyses extension for Scoping Reviews) framework. A total of 7499 articles were found in 4 medical databases (PubMed, Ovid, Web of Science, and CINAHL). Studies were eligible if they used noninvasive wearables: worn on the wrist, arm, hip, and chest; measured vital signs; and analyzed the collected data quantitatively. We excluded studies that did not use wearables for outcome assessment and prototype studies, devices that cost $>€ 500$ (US \$570), or obtrusive smart clothing.

Results: We included 179 studies using 189 wearable devices covering 10,835,733 participants. Most studies were observational $(128 / 179,71.5 \%)$, conducted in $2020(56 / 179,31.3 \%)$ and in North America $(94 / 179,52.5 \%)$, and 93\% (10,104,217/10,835,733) of the participants were part of global health studies. The most popular wearables were fitness trackers $(86 / 189,45.5 \%)$ and accelerometer wearables, which primarily measure movement $(49 / 189,25.9 \%)$. Typical measurements included steps $(95 / 179$, $53.1 \%)$, heart rate (HR; 55/179, 30.7\%), and sleep duration $(51 / 179,28.5 \%)$. Other devices measured blood pressure $(3 / 179$, $1.7 \%)$, skin temperature $(3 / 179,1.7 \%)$, oximetry $(3 / 179,1.7 \%)$, or respiratory rate $(2 / 179,1.1 \%)$. The wearables were mostly worn on the wrist $(138 / 189,73 \%)$ and cost $<€ 200$ (US $\$ 228 ; 120 / 189,63.5 \%)$. The aims and approaches of all 179 studies revealed six prominent uses for wearables, comprising correlations-wearable and other physiological data (40/179, 22.3\%), method evaluations (with subgroups; 40/179, 22.3\%), population-based research $(31 / 179,17.3 \%)$, experimental outcome assessment $(30 / 179,16.8 \%)$, prognostic forecasting $(28 / 179,15.6 \%)$, and explorative analysis of big data sets $(10 / 179,5.6 \%)$. The most frequent strengths of affordable wearables were validation, accuracy, and clinical certification $(104 / 179,58.1 \%)$. 
Conclusions: Wearables showed an increasingly diverse field of application such as COVID-19 prediction, fertility tracking, heat-related illness, drug effects, and psychological interventions; they also included underrepresented populations, such as individuals with rare diseases. There is a lack of research on wearable devices in low-resource contexts. Fueled by the COVID-19 pandemic, we see a shift toward more large-sized, web-based studies where wearables increased insights into the developing pandemic, including forecasting models and the effects of the pandemic. Some studies have indicated that big data extracted from wearables may potentially transform the understanding of population health dynamics and the ability to forecast health trends.

(JMIR Mhealth Uhealth 2022;10(1):e34384) doi: $10.2196 / 34384$

\section{KEYWORDS}

wearable; consumer-grade wearables; commercially available wearables; public health; global health; population health; fitness trackers; big data; low-resource setting; tracker; review; mHealth; research; mobile phone

\section{Introduction}

\section{Background}

Wearable devices hold great promise, particularly for data generation for cutting-edge health research, and their demand has risen considerably in the last few years [1-3].

Noninvasive, consumer-grade wearables (hereafter wearables) may provide manifold advantages for health research; they are generally unobtrusive, less expensive than gold standard research devices [4], comfortable to wear [5], and affordable for consumers [6]. In recent years, the quality and accuracy of wearables have improved [7,8], resulting in more clinically approved certifications [9]. Wearables can measure long-term data in the naturalistic environment of study participants, allowing for ecologic momentary assessments [10,11]. Therefore, wearables are valuable developments, particularly for generating data for health research in large study populations, that is, global health or epidemiological studies, or in low-income contexts $[6,9,12]$.

One example of a large study is the so-called Datenspende study by the Robert Koch Institute, the German research institute for disease control and prevention, which aims to tackle the COVID-19 (corona virus disease) pandemic with anonymous data donations acquired through wearables [13]. On the basis of the study by Radin et al [14], researchers used wearable data to calculate the regional probability of COVID-19 outbreaks incorporating data on pulse, physical activity (PA), and sleep, as well as weather data. Using a large sample size exceeding half a million participants, they forecasted the number of COVID-19 infections for the preceding 4 days. The Apple Heart Study [15] is another example that was a breakthrough for showing that wearable devices may detect atrial fibrillation (AF) and foster a discussion of potentials and limitations with regard to health care providers, researchers, and members of the media and economy $[16,17]$.

Apart from these 2 examples, wearables are applied in diverse fields of health, including acoustic, gastrointestinal sensors for ileus prediction [18]; UV sun exposure [19]; heat-related illness measurements [20]; electrolyte monitoring, for example, for cystic fibrosis or training management [21,22]; early warning of AF with a wearable ring [23]; generation of electrocardiograms (ECGs) [15]; measurement of cardiopulmonary resuscitation quality [24]; measurement of continuous noninvasive blood glucose [25], as well as smart inhalers and activity trackers for asthma monitoring [26].

Numerous reviews and studies have investigated validation and accuracy, particularly for specific affordable wearables, comparing these to the gold standard measurements [21] or comparing evidence in a meta-analysis [8]. Many studies have focused on novel technologies, presenting prototypes, or investigating the feasibility and acceptance of a wearable device in a specific setting $[3,27]$. Similarly, reviews on the application and potential of wearables have focused on (1) specific wearable devices or specific wearable measurements, for example, only smartwatches [4] or only sleep measurements [28] or (2) applications of specific medical fields and interventions, for example, only for diagnosis and treatment in cardiological conditions [29] or wearables as an intervention to promote PA in patients with oncologic conditions [30]. Among these publications, we identified a lack of aggregated insight for wearable use in health research and its respective strengths and shortcomings.

\section{Objectives}

With this scoping review, we aim to overview and categorize the current research conducted on wearable devices.

\section{Methods}

\section{Overview}

We conducted a scoping review to explore the applications of affordable wearables worn on wrists, arms, chests, or waists, which constitute the characteristic locations [31]. We focused on the following aspects: (1) demographics; (2) wearable devices and measured vital signs; (3) wearable data and its analysis; (4) reported shortcomings and strengths of wearables; and (5) study aims, results, and types of wearable use. We present our findings in accordance with the PRISMA (Preferred Reporting Items for Systematic Reviews and Meta-Analyses) reporting standard and PRISMA-ScR (Preferred Reporting Items for Systematic Reviews and Meta-Analyses extension for Scoping Reviews; Multimedia Appendix 1) [32] and the methodological framework of Arksey and O'Malley [33] and Peters et al [34]. A scoping review seemed most appropriate given the broad nature of this subject and the range of potential implementations in the setting of health research. 


\section{Eligibility Criteria}

We sought to define and characterize the state of affordable wearables for health research. Eligible publications were peer reviewed, published in English, and published after 2013 (after wearables became widely commercially available [1-3]) and had a full-text version available (in instances no full text was available, authors were contacted 3 times with a waiting period of 7 days between each contact before exclusion).

Our review scopes the current information available on affordable, noninvasive wearables, which are (1) worn on the wrist, arm, and chest; (2) measure vital signs; and (3) analyze the generated wearable data for outcome assessment. Validation and qualitative studies were excluded. We focused only on devices that cost $<€ 500$ (US \$570) per device (1) to allow the affordability of larger studies, for example, where wearable devices need to be provided to study participants via the study and (2) to ensure that wearables are available commercially and (3) intended for consumers. As the definition of vital signs is not distinct [35], we included the following vital signs [9,36,37]: HR, HR variability, ECG measurements or heart rhythm analysis (detection of arrhythmias), blood pressure, blood oxygen, respiratory rate, body temperature, sleep, electrodermal activity, electromyogram measurements, and PA (Textbox 1).

Textbox 1. Inclusion and exclusion criteria.

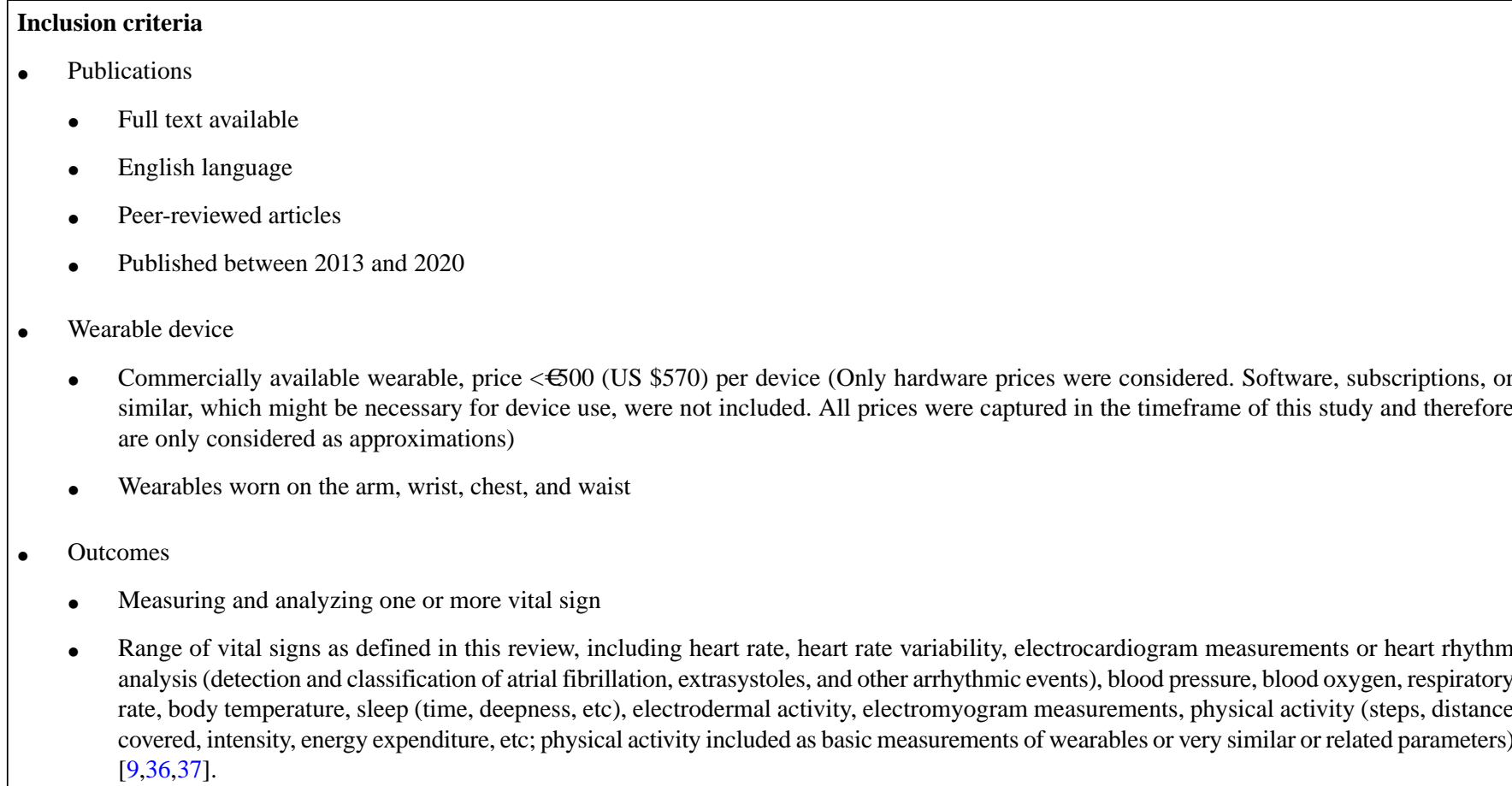

\section{Exclusion criteria}

- Publications

- Studies not analyzing wearable-generated data for (health) outcome assessment, including studies focusing on (1) accuracy, validation, improvement (algorithms and software); (2) patents; (3) smart clothing; (4) obtrusive wearables (the device comprises obstructive parts or wires, etc); (5) behavior change intervention studies (ie, where the wearable is provided as promotion for more physical activity only and not for health outcome assessment); (6) qualitative studies; or (7) studies with research objectives and outcomes not related to health or a medical condition

- Wearable device

- Wearable not commercially available (eg, prototype and discontinued)

- Invasive, obtrusive device (comprising obstructive parts or wires, etc)

- $\quad$ Prosthesis, smart clothing (sensors in clothing)

- $\quad$ Outcomes

- Not measuring vital sign, that is, gait, posture, and motion recognition analysis (eg, gesture recognition for sign language)

- Studies with research objectives and outcomes not related to health or a medical condition 


\section{Information Sources and Search}

We used PubMed, Ovid, Web of Science, and CINAHL to search peer-reviewed literature using a search string based on the following three concepts: synonyms and medical subject headings terms, including (1) wearables (synonyms, top 15 vendors with most market shares [38-40], or frequently used in research [2,7]), (2) physical wear location of wearables (torso, arm, and wrist), and (3) measurement of vital signs (for full search string see Multimedia Appendix 2 [41]). We manually searched the reference lists for relevant articles.

We imported the identified articles into the literature reference management system Zotero [42] and then into the systematic review management platform Covidence [41]. Literature was screened by 2 independent reviewers. Any disagreements were resolved by discussion between the 2 reviewers ( $\mathrm{SH}$ and $\mathrm{MA}$ ) and a third researcher $(\mathrm{SB})$.

\section{Quality Assessment}

To assess the quality of the included studies and their various study designs (credibility), we considered the Medical Education Research Study Quality Instrument [43] score as adequate (Multimedia Appendix 3 [14,15,20,44-219]).

\section{Data Synthesis}

We conducted data synthesis in accordance with Arksey and O'Malley [33], comprising the analytic framework, analysis of the extent and nature of studies, and thematic analysis. We categorized the findings by title, author, year, country of study, objectives of study, study population, sample size, methods, intervention type, outcomes, and key findings related to the scoping review question [34]. We extracted mutually exclusive groups, including wearable manufacturers, built-in sensors, scope of measurements (vital signs), shortcomings and strengths of wearables mentioned by the authors, the used methods for data analysis, and medical fields.

\section{Results}

\section{Overview}

Our initial search yielded 7499 hits (PubMed: 2514; Ovid: 1905; Web of Science: 1440; CINAHL: 1640) and we identified 121 publications by manual search. Of 7620 total publications, we screened 4525 (59.38\%) nonduplicates for title and abstract, leading to the assessment of 660 full-texts. After full-text screening of the 660 articles, we included $179(27.1 \%)$ studies in our review [14,15,20,44-219] (Figure 1). 
Figure 1. PRISMA (Preferred Reporting Items for Systematic Reviews and Meta-Analyses) flow diagram [220].

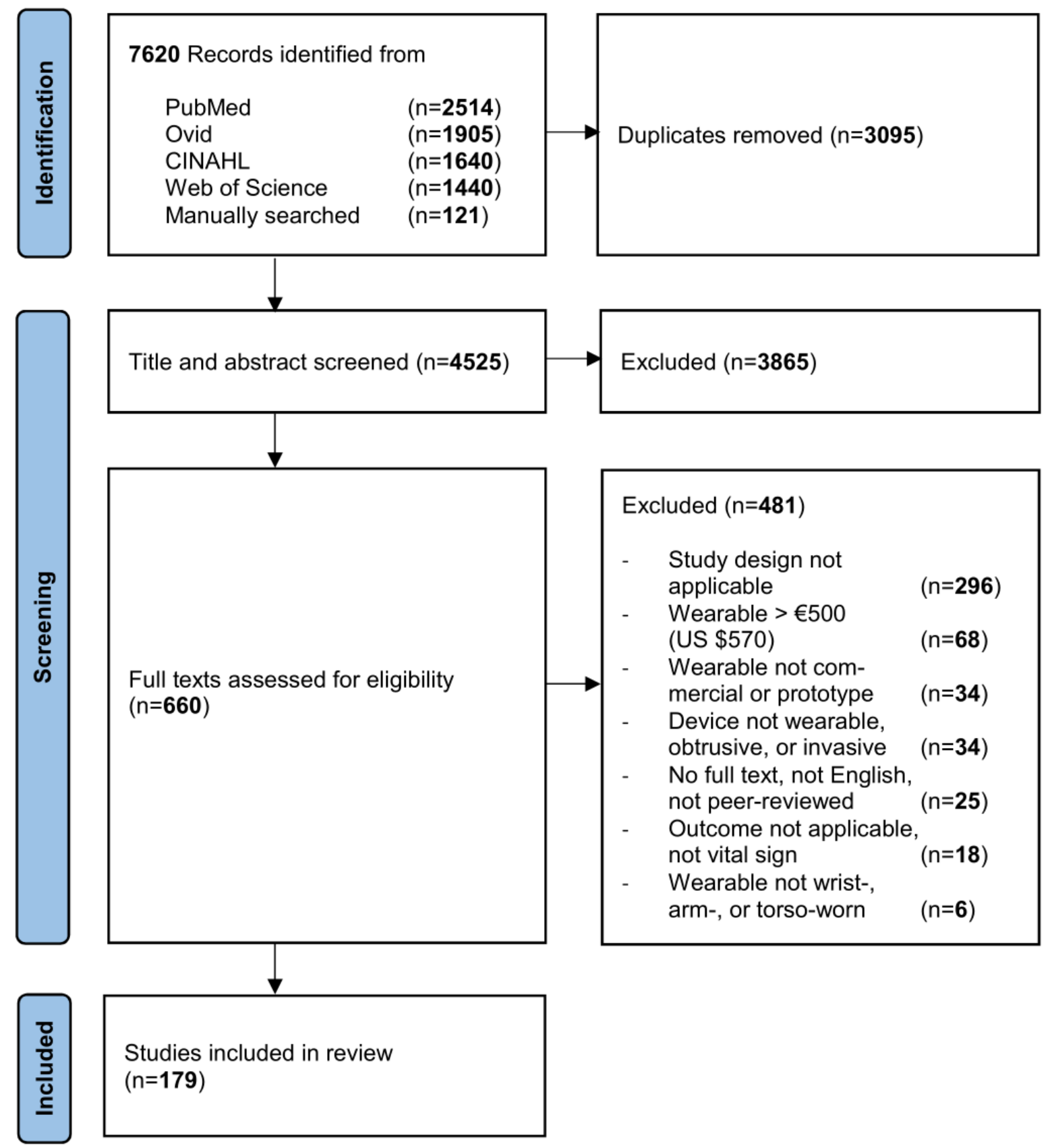

\section{Study Characteristics}

\section{Demographics}

Between 2013 and 2020, we observed an increase in the number of studies and study participants (Figure 2 and Table 1). The year 2019 featured the largest sample size, and studies were predominantly conducted in North America (Figure 3 [221]).
The largest study we identified was conducted in 2019 in North America and included over 8 million participants $(75.71 \%)$ [153]; the second largest was a European study comprising 742,000 participants $(6.85 \%)$ [162]. Without the aforementioned, largest study, Europe and Asia would lead in participant numbers and we would see a continuous increase in participant numbers from 2013 to 2020. 
Figure 2. Number of studies and study participants (logarithmic scale) per year of study publication. The sizes of the circles visualize the overlapping and number of studies within the year.

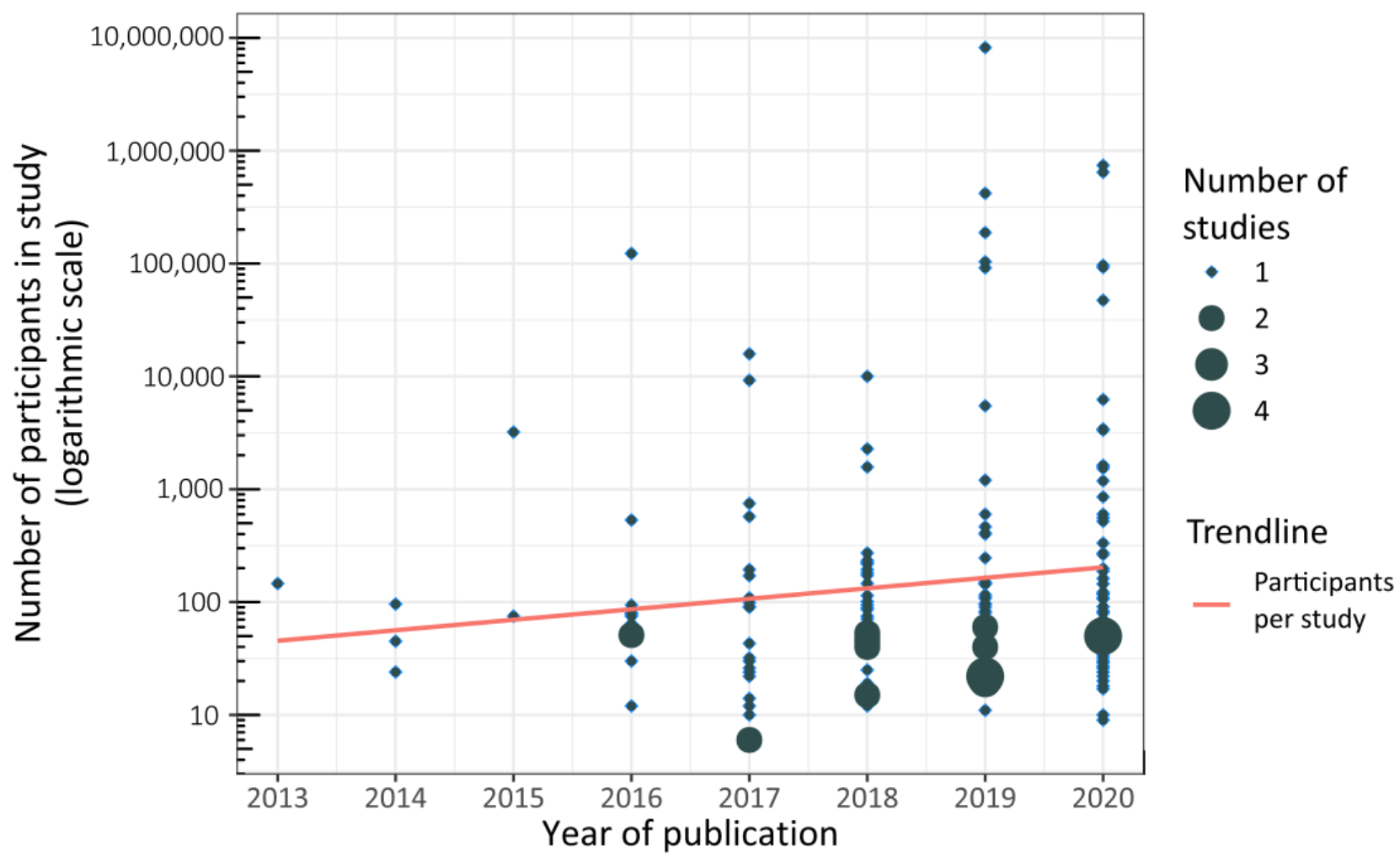


Table 1. Characteristics of studies.

\begin{tabular}{|c|c|c|}
\hline Study characteristics & Studies $(\mathrm{N}=179), \mathrm{n}(\%)$ & Participants $(\mathrm{N}=10,835,733), \mathrm{n},(\%)$ \\
\hline \multicolumn{3}{|l|}{ Year of publication } \\
\hline 2013 & $1(0.56)$ & $146(<0.01)$ \\
\hline 2014 & $3(1.68)$ & $165(<0.01)$ \\
\hline 2015 & $2(1.12)$ & $3284(0.03)$ \\
\hline 2016 & $14(7.82)$ & $124,060(1.14)$ \\
\hline 2017 & $21(11.73)$ & $27,377(0.25)$ \\
\hline 2018 & 34 (18.99) & $16,700(0.15)$ \\
\hline 2019 & $48(26.82)$ & $9,016,909(83.21)$ \\
\hline 2020 & $56(31.28)$ & $1,647,092(15.2)$ \\
\hline \multicolumn{3}{|l|}{ Continents } \\
\hline North America & $94(52.51)$ & $8,916,888(82.29)$ \\
\hline Europe & $50(27.93)$ & $991,357(9.15)$ \\
\hline Asia & $24(13.41)$ & $925,768(8.54)$ \\
\hline Australia & $8(4.47)$ & $1198(0.01)$ \\
\hline South America & $3(1.68)$ & $522(<0.01)$ \\
\hline \multicolumn{3}{|l|}{ Study objectives } \\
\hline Correlations and influencing factors of study population and outcome data ${ }^{a}$ & $70(39.11)$ & $394,296(3.64)$ \\
\hline Population and patient characterization ${ }^{\mathrm{b}}$ & $54(30.17)$ & $8,315,559(76.74)$ \\
\hline Evaluation of method or intervention & $47(26.26)$ & $2,124,328(19.6)$ \\
\hline Prognostic evaluation $^{c}$ & $8(4.5)$ & $1550(0.01)$ \\
\hline \multicolumn{3}{|l|}{ Study design } \\
\hline Cross-sectional study & $66(36.87)$ & $9,780,808(90.26)$ \\
\hline Cohort study & $62(34.64)$ & $628,641(5.8)$ \\
\hline Nonrandomized experimental study & $14(7.82)$ & $724(0.01)$ \\
\hline Randomized controlled trial & $11(6.15)$ & $2332(0.02)$ \\
\hline Method evaluation & $8(4.47)$ & $314,247(2.9)$ \\
\hline Other & $7(3.91)$ & $108,462(1)$ \\
\hline Case control study & $7(3.91)$ & $348(<0.01)$ \\
\hline Mixed methods, feasibility study & $4(2.23)$ & $171(<0.01)$ \\
\hline \multicolumn{3}{|l|}{ Medical field of study } \\
\hline Multidisciplinary and general medicine & $43(24.02)$ & $107,148(0.99)$ \\
\hline Neurology and psychiatry & $29(16.2)$ & $2630(0.02)$ \\
\hline Cardiology, fitness, and sports medicine & $28(15.64)$ & $557,120(5.14)$ \\
\hline Global health, epidemiology, and prevention & $19(10.61)$ & $10,104,217(93.25)$ \\
\hline Gynecology and pediatrics & $18(10.06)$ & $5575(0.05)$ \\
\hline Orthopedics and surgery & $16(8.94)$ & $2749(0.03)$ \\
\hline Pulmonology & $13(7.26)$ & $1326(0.01)$ \\
\hline Other & $13(7.26)$ & $54,968(0.51)$ \\
\hline
\end{tabular}

${ }^{a}$ Studies aimed to find associations, correlations, or influencing factors within their study population, study outcomes, and generated data.

${ }^{\mathrm{b}}$ Studies aimed to observe and characterize the study population and patients.

${ }^{\mathrm{c}}$ Studies aimed to evaluate patient-reported outcomes, health care practices, diagnostics, screenings, and others. 
Figure 3. Included studies per continent. The colors of the continents visualize the number of included studies published on the respective continent (created with Mapchart [221]).

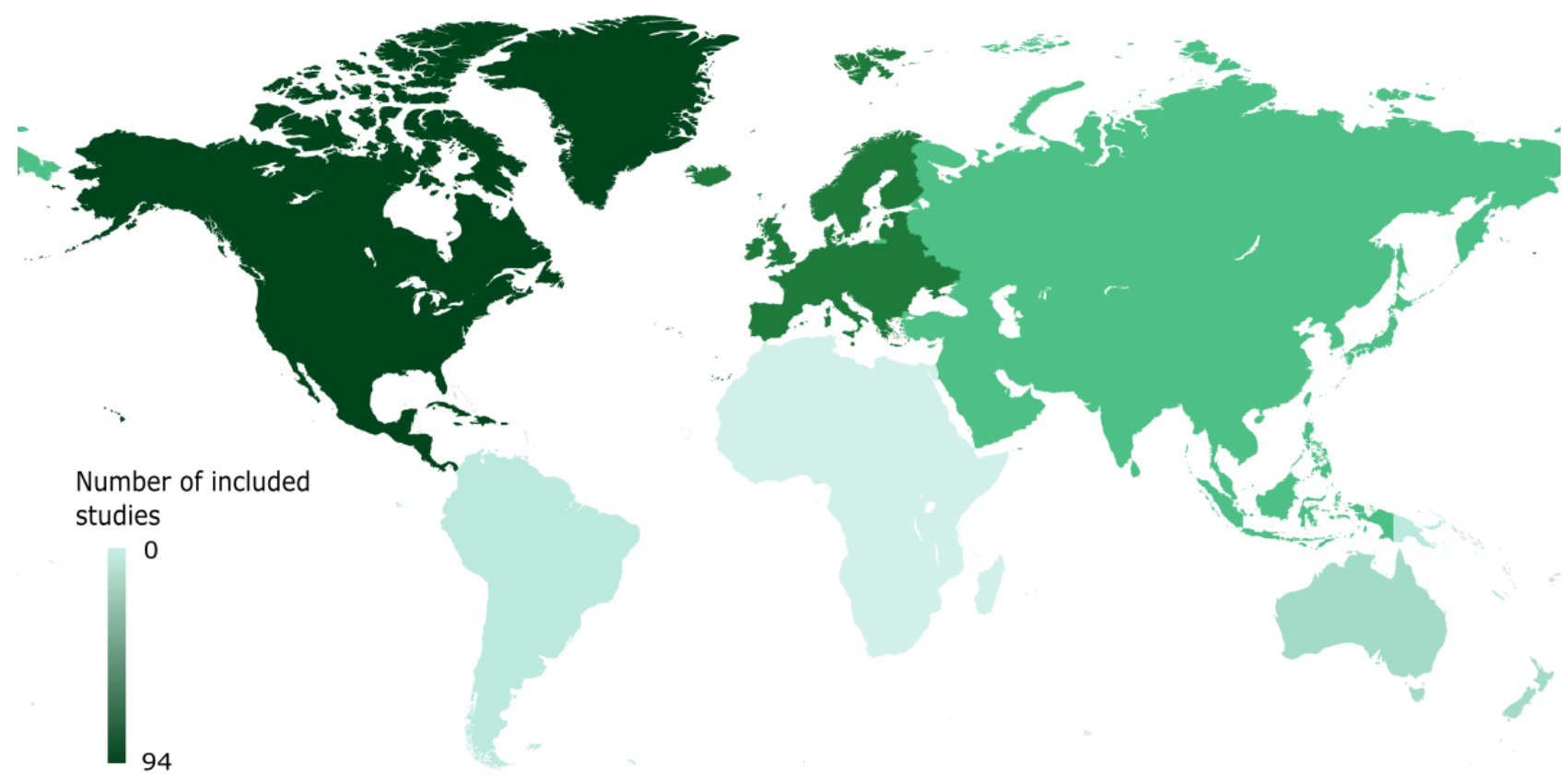

\section{Study Types and Fields}

Most studies (128/179, 71.5\%) used observational study designs such as cross-sectional $(66 / 179,36.9 \%)$ and cohort studies $(62 / 179,34.6 \%)$, comprising 9,780,808 $(90.26 \%)$ participants and 628,641 (5.8\%) participants, out of 10,835,733 participants, respectively. Most frequently, studies $(70 / 179,39.1 \%)$ aimed to find associations, correlations, or influencing factors within their study population, study outcomes, and generated data.
Slightly less than one-third of the studies $(54 / 179,30.2 \%)$ aimed to characterize and observe their study population.

Most studies were conducted in the fields of multidisciplinary and general medicine $(43 / 179,24 \%)$; cardiology, fitness, and sports medicine $(29 / 179,16.2 \%)$; and neurology, psychology, and psychiatry $(28 / 179,15.6 \%$; Figure 4$)$. The fields of global health, prevention, and epidemiology featured the largest sample size with, with $10,104,217(93.25 \%)$ out of $10,835,733$ participants. 
Figure 4. Studies per medical field.

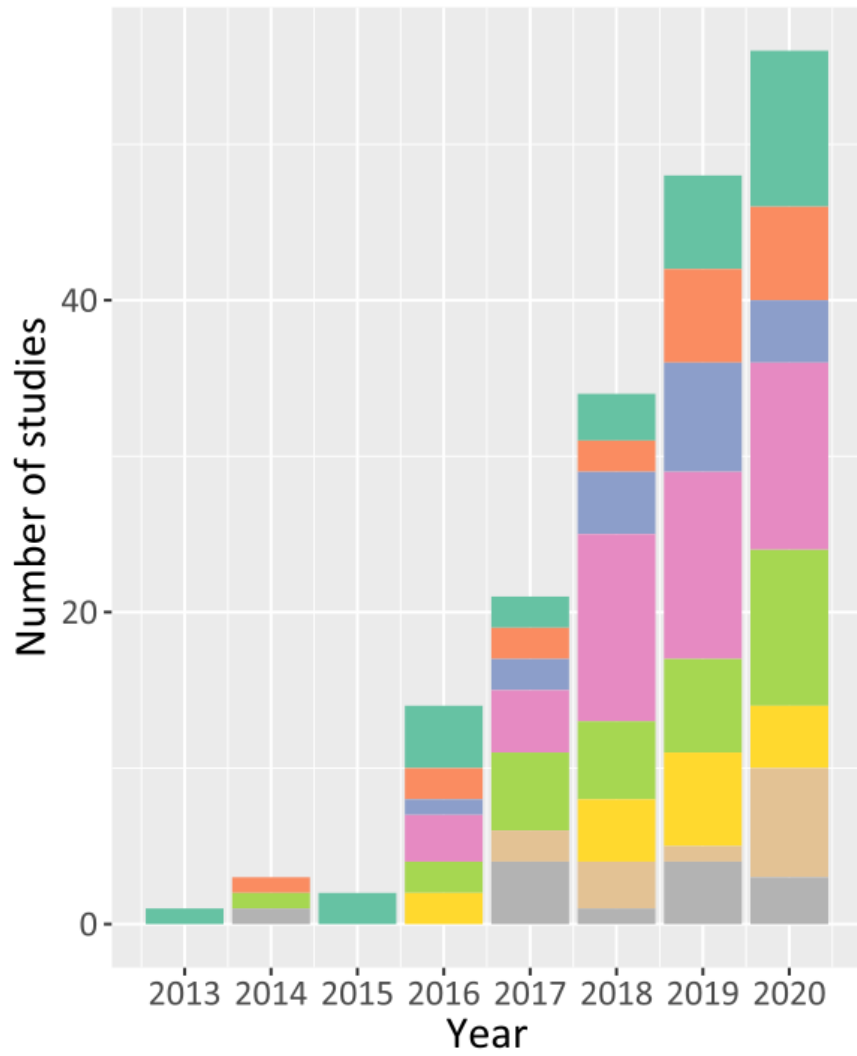

Wearable Characteristics

A total of 189 wearable devices were extracted. The company with the most wearable devices in the included studies was Fitbit $(97 / 189,51.3 \%)$, covering 8,361,035 (74.35\%) out of $11,224,872$ participants. Fitbit is followed by ActiGraph

\section{Medical fields}

Cardiology, fitness and sports medicine Global Health, epidemiology, and prevention Gynecology and paediatrics Multidisciplinary and internal medicine Neurology and psychiatry Orthopaedics and surgery Other Pulmonology (research-grade wearable devices unavailable for consumers or not consumer grade per se; $19 / 189,10.1 \%)$, Polar Electro $(9 / 189$, $4.8 \%)$, and Withings $(8 / 189,4.2 \%)$. In number of study participants, Huawei and Withings comprised 832,036 (7.4\%) participants and 794,174 (7.06\%) participants out of 11,224,872 participants, respectively (Table 2). 
Table 2. Characteristics of wearable devices.

\begin{tabular}{|c|c|c|}
\hline Wearable characteristics & Studies (N=189), n (\%) & Participants $(\mathrm{N}=11,244,872), \mathrm{n}(\%)$ \\
\hline \multicolumn{3}{|l|}{ Wearable companies used in studies } \\
\hline Fitbit & $97(51.32)$ & $8,361,035(74.35)$ \\
\hline ActiGraph $^{\mathrm{a}}$ & $19(10.05)$ & $2571(0.02)$ \\
\hline Polar electro & $9(4.76)$ & $6970(0.06)$ \\
\hline Withings & $8(4.23)$ & $794,174(7.06)$ \\
\hline iRhythm & $6(3.17)$ & $128,641(1.14)$ \\
\hline Xiaomi & $5(2.65)$ & $176(<0.01)$ \\
\hline Axivity $^{\mathrm{a}}$ & $4(2.12)$ & $291,871(2.6)$ \\
\hline Garmin & $4(2.12)$ & $308(<0.01)$ \\
\hline Apple & $4(2.12)$ & $420,826(3.74)$ \\
\hline Activinsights ${ }^{\mathrm{a}}$ & $3(1.59)$ & $1971(0.02)$ \\
\hline Samsung & $2(1.06)$ & $120(<0.01)$ \\
\hline Ava AG & $2(1.06)$ & $285(<0.01)$ \\
\hline Huawei & $2(1.06)$ & $832,036(7.40)$ \\
\hline Whoop & $2(1.06)$ & $305(<0.01)$ \\
\hline Omron & $2(1.06)$ & $159(<0.01)$ \\
\hline Other companies (wearable only included in 1 study) & $20(10.58)$ & $423,424(3.77)$ \\
\hline \multicolumn{3}{|l|}{ Number of wearable device models per study $(n=179)$} \\
\hline 1 & $156(87.15)$ & $486,684(4.49)$ \\
\hline 2 & $11(6.15)$ & $420,007(3.88)$ \\
\hline 3 & $3(1.68)$ & $838,266(7.74)$ \\
\hline$>3$ or not applicable ${ }^{b}$ & $9(5.03)$ & $9,090,776(83.9)$ \\
\hline \multicolumn{3}{|l|}{ Wearable device types } \\
\hline Fitness tracker & $86(45.5)$ & $22,823(0.2)$ \\
\hline Accelerometer (worn on wrist, torso, and hip) & $49(25.93)$ & $299,251(2.66)$ \\
\hline Electrocardiogram chest patch or strap & $21(11.11)$ & $530,332(4.72)$ \\
\hline Smartwatch & $12(6.35)$ & $1,259,605(11.2)$ \\
\hline Diverse wearable devices_-secondary data via wearable data platform & $11(5.82)$ & $9,122,758(81.13)$ \\
\hline $\begin{array}{l}\text { Distinct vital sign trackers (eg, oximetry ring, temperature wristband tracker, } \\
\text { and blood pressure armband) }{ }^{\mathrm{c}}\end{array}$ & $10(5.29)$ & $10,103(0.09)$ \\
\hline \multicolumn{3}{|l|}{ Physical location of wearable } \\
\hline Wrist & $138(73.02)$ & $10,702,843(95.18)$ \\
\hline Hip & $25(13.23)$ & $2257(0.02)$ \\
\hline Chest & $21(11.11)$ & $550,332(4.89)$ \\
\hline Arm & $3(1.59)$ & $9392(0.08)$ \\
\hline Finger & $2(1.06)$ & $48(<0.01)$ \\
\hline \multicolumn{3}{|l|}{ In studies used in-built sensor in wearables ${ }^{d}(n=179)$} \\
\hline Accelerometer & $146(81.56)$ & $1,157,069(10.68)$ \\
\hline Photoplethysmography & $59(32.96)$ & $9,622,147(88.8)$ \\
\hline Electrodes (ie, electrocardiogram) & $21(11.73)$ & $550,500(5.08)$ \\
\hline Gyroscope & $6(3.35)$ & $1585(0.01)$ \\
\hline
\end{tabular}




\begin{tabular}{|c|c|c|}
\hline Wearable characteristics & Studies $(\mathrm{N}=189), \mathrm{n}(\%)$ & Participants $(\mathrm{N}=11,244,872), \mathrm{n}(\%)$ \\
\hline Thermometer & $4(2.23)$ & $842(0.01)$ \\
\hline Blood pressure sensor & $3(1.68)$ & $9397(0.09)$ \\
\hline \multicolumn{3}{|l|}{ Wearable costs $(€ ;$ US \$) } \\
\hline$<200(228)$ & $120(63.49)$ & $340,460(3.03)$ \\
\hline $200-350(228-399)$ & $41(21.69)$ & $18,256(0.16)$ \\
\hline$>350$ (399) & $13(6.88)$ & $551,128(4.9)$ \\
\hline Not applicable $e^{\mathrm{e}}$ & $15(7.94)$ & $10,355,028(92.09)$ \\
\hline \multicolumn{3}{|l|}{ Analysis-statistical tests ${ }^{\mathrm{f}}$ in studies $(\mathrm{n}=179)$} \\
\hline Regression & $62(34.64)$ & $1,021,032(9.42)$ \\
\hline$t$ test & $41(22.91)$ & $8,309,202(76.68)$ \\
\hline Correlation (Pearson, Spearman, etc) & $40(22.35)$ & $11,044(0.1)$ \\
\hline Wilcoxon $U$, Mann-Whitney $U$, and other nonparametric tests & $23(12.85)$ & $7180(0.07)$ \\
\hline Chi-square and Fisher-Yates tests & $15(8.38)$ & $433,785(4)$ \\
\hline Mixed methods model and other statistical models & $14(7.82)$ & $57,938(0.53)$ \\
\hline Artificial Intelligence (data mining, cluster, machine learning, etc) & $11(6.15)$ & $835,967(7.71)$ \\
\hline Analysis of variance & $11(6.15)$ & $810(0.01)$ \\
\hline Descriptive & $8(4.47)$ & $423,093(3.9)$ \\
\hline Prognostic analysis (Kaplan-Meier, permutation test, etc) & $3(1.67)$ & $420,928(3.88)$ \\
\hline
\end{tabular}

${ }^{\mathrm{a}}$ Research-grade wearable devices unavailable for consumers or not consumer grade per se.

${ }^{\mathrm{b}}$ Studies collected data with multiple wearable devices (that belonged to the study participants) or studies that used secondary data provided by web-based wearable platforms, mobile applications, or wearable companies.

${ }^{\mathrm{c}}$ Distinct vital sign trackers are specialized on a specific vital sign, for example, oximetry ring, temperature wristband tracker, and blood pressure armband. They differ in measured vital signs and worn locations compared with other wearable device types.

${ }^{\mathrm{d}}$ Utilized in-built sensors in wearables sums up to more than the total of wearables, as sometimes more than one built-in sensor was used.

${ }^{\mathrm{e}}$ Providing wearable hardware pricing was not transparent, as some studies used data provided by diverse participant-owned wearables or wearable hardware costs were part of a subscription or a membership fee, that is, Whoop strap of Whoop.

${ }^{\mathrm{f}}$ Analysis - statistical tests sums up to more than the total number of included studies, as some studies applied more than one type of analysis or statistical test.

Most studies $(156 / 179,87.2 \%)$ used 1 wearable model. However, most of the study participants $(9,090,776 / 10,835,733$, $83.9 \%$ ) were part of large-scale population-based studies in which data were mostly collected with multiple wearable devices that belonged to the study participants.

Some large-scale population-based studies $(11 / 179,6.1 \%)$ relied on secondary data collected with mobile apps [87] or web-based wearable platforms [153] or provided through a wearable company [189]. Thus, the device type could not be specified (assigned to category diverse wearable devices-secondary data via wearable data platform). A total of $15(63 \%)$ out of 24 studies that used secondary data were conducted in 2020 , and $5(21 \%)$ studies in 2019.
Fitness trackers $(86 / 189,45.5 \%)$ and accelerometers (measuring body movement acceleration [37]) worn on the wrist, torso, and hip $(49 / 189,25.9 \%)$ were the most frequent. Other wearable device types included ECG chest straps and patches (21/189, $11.1 \%)$, smartwatches $(12 / 189,6.3 \%)$, and distinct vital sign trackers $(10 / 189,5.3 \%)$ such as oximetry rings or blood pressure armbands (Table 2).

Most wearables were worn on the wrist $(138 / 189,73 \%)$, followed by the hip $(25 / 189,13.2 \%)$ and chest $(21 / 189,11.1 \%)$. Only a few wearables were worn on the arm $(3 / 189,1.6 \%)$ and finger (2/189, 1.1\%; Figure 5). 
Figure 5. Wear locations of wearables and their frequencies. The color and size of the circles assigned to the body location visualize the frequency of wearables worn on the respective location.

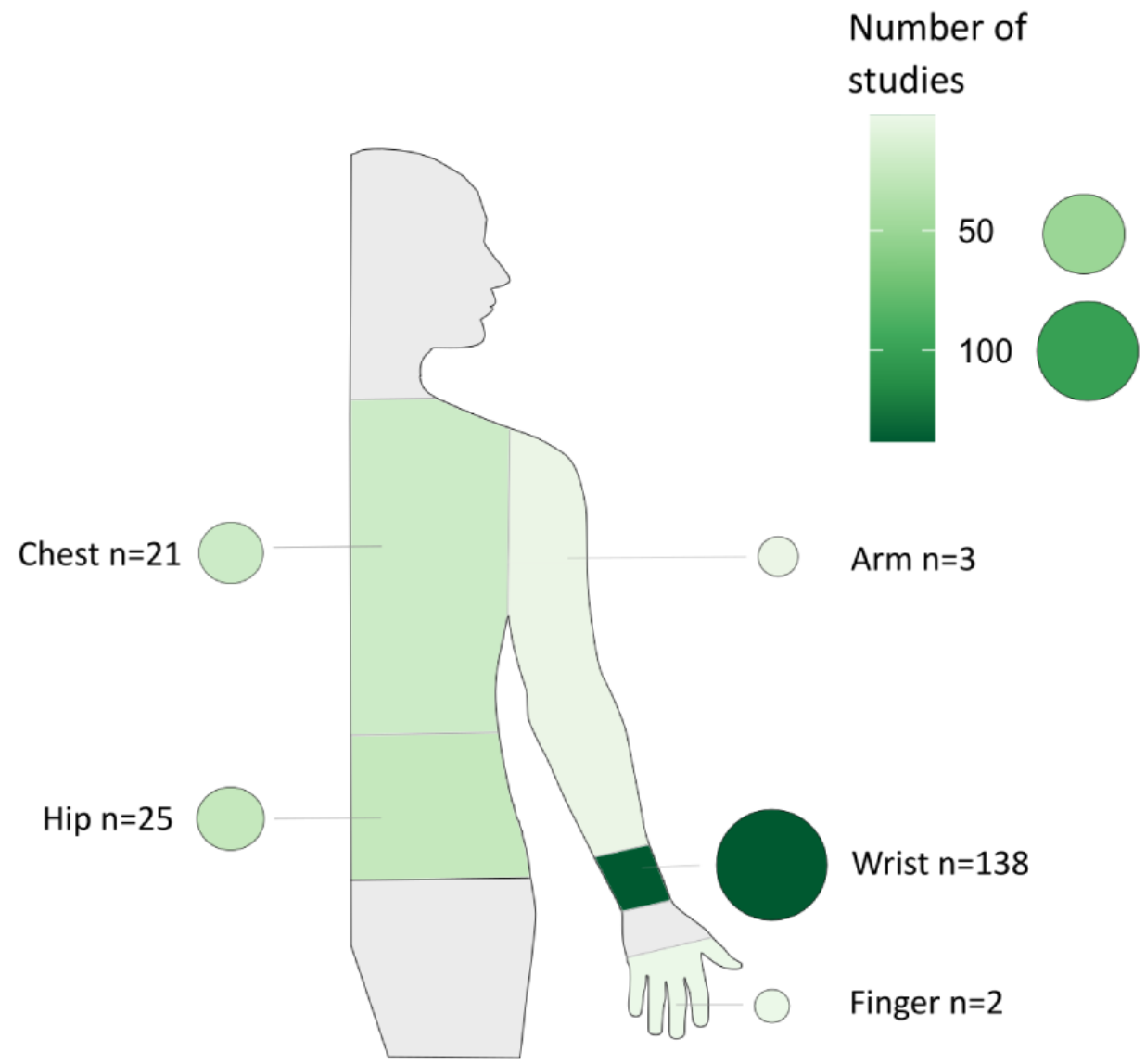

Most of the studies used wearable built-in sensors of (1) accelerometers $(146 / 179,81.6 \%)$ that measure acceleration on a 3- or 1-axis [37] and (2) photoplethysmography (59/179, 33\%) defined as an "optical technique that [...] detects blood volume changes in the microvascular bed of tissue" [222]. Other built-in sensors were electrodes for ECG measurements $(21 / 179,11.7 \%)$; gyroscopes $(6 / 179,3.4 \%)$, which determine how different portions of the body rotate [37]; thermometers $(4 / 179,2.2 \%)$ measuring skin temperature; and blood pressure sensors $(3 / 179$, $1.7 \%)$.

Most studies investigated steps $(95 / 179,53.1 \%)$, HR (55/179, $30.7 \%)$, and sleep time $(51 / 179,28.5 \%)$. We classified measured vital signs into three categories, whereby PA measures were most frequent $(228 / 179,127.4 \%$; Multimedia Appendix 4 [14,15,20,44-219]):

1. PA measures included steps, intensity (eg, time spent in moderate to vigorous PA), energy expenditure (eg, kilocalories and metabolic equivalent), axial or raw movement data, distance (covered), and others (such as stairs taken, elevation, and sedentary time).

2. Cardiac measures included HR, HR variability, and ECG (or other direct heart rhythm analyses, such as AF detection).

3. Other measures that included blood or pulse pressure, body temperature, blood oxygen, and respiratory rate.
Most studies (120/189, 63.5\%) used wearables that cost $<€ 200$ (US \$228). In some studies (15/189, 7.9\%), wearable prices were not transparent, as data were provided through a variety of participant-owned wearables [87] or the wearable hardware was part of a subscription or a membership fee, that is, Whoop strap of Whoop [178].

Regression analysis $(62 / 179,34.6 \%)$ and $t$ tests $(42 / 179,22.9 \%)$ were the most commonly used statistical methods to analyze wearable data. Other methods comprised nonparametric tests, such as correlations, Wilcoxon U test, Kaplan-Meier survival analysis, and chi-square tests. Variance analysis (analysis of variance) and significance tests such as permutations were also used. Further data analyses were conducted in a data-driven manner [223] with artificial intelligence, such as k-means [176] or unsupervised cluster analysis [172], recursive feature elimination technique [170], rotation random forest classifier [130], and supervised machine learning algorithms using logistic regression, decision tree, and random forest [215].

\section{Categorization of Wearable Application in the Studies}

We categorized the included studies based on their study objective, the role of the wearable and the collected wearable data within the study in the following 6 categories (overlaps are possible as separation is artificial). In the following, categories are presented in order of their frequency (see Figure 6 and Multimedia Appendix 5 [14,15,20,44-219] for article references and examples). 
Figure 6. Categorization of wearable applications, showing proportions of the 6 categories (with 4 subcategories). The size of depicted categories (in different colors) corresponds to the number of studies.

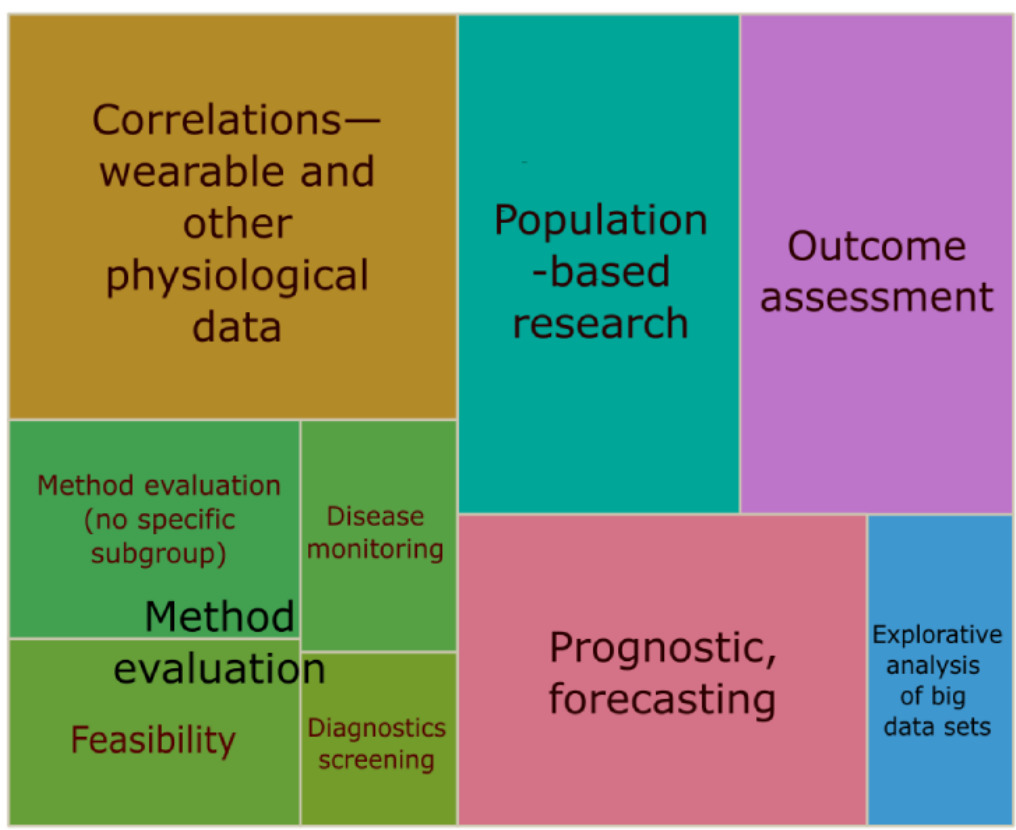

\section{Correlations-Wearable and Other Physiological Data}

Studies $(40 / 179,22.3 \%)$ have examined the correlation of a wearable derived measure with clinical- and patient-reported and other health-related outcomes to find new associations and correlations. The data generated by the wearable device were correlated with data from mostly physiological or patient-reported outcomes.

\section{Population-Based Research}

In $17.3 \%$ (31/179) of studies, wearables produced insights into a specific population through monitoring (observational and cross-sectional) of vital signs, such as steps and HR. Often, these were cross-sectional studies $(17 / 31,55 \%)$ where the wearable measurement was the sole outcome. The resulting data provide novel insights and characteristics of populations.

\section{Outcome Assessment}

In these studies $(30 / 179,17.3 \%)$, wearables generated the outcome measurement and monitored the dependent variable in an (quasi-) experimental setting or intervention, in mostly randomized controlled trials and quasi-experimental designs.

\section{Prognosis, Forecasting, and Risk Stratification}

In further studies $(28 / 179,15.6 \%)$, data generated with wearables were integrated into risk calculations (risk for a certain event or outcome), prognostic models, or cut-points. Wearable data constituted inputs for models to estimate risks.

\section{Explorative Analysis of Big Data Sets}

These studies (10/179, 5.6\%) exploratively analyzed big data [223], generated by wearables and accessible via applications, commercial platforms, eCohorts, or companies themselves, to find trends and generate new hypotheses.

\section{Method Evaluation}

Studies $(40 / 179,22.3 \%)$ have evaluated and compared methods and tools (such as screenings for diseases, general practices, questionnaires, or other patient-reported outcomes) with the help of wearables. The wearable device might be the gold standard device or probed itself.

\section{Feasibility}

In these studies $(12 / 179,6.7 \%)$, the feasibility of using wearables for screening diseases and to improve on existing methods and practices is focused, mostly accompanied by a qualitative component.

\section{Diagnostics and Screening}

Studies $(6 / 179,3.4 \%)$ in this category evaluated details of diagnostics and disease screening outcomes, (cost-) effectiveness, utility, and screening length or were compared with standard measurement methods.

\section{Disease Monitoring}

Here $(8 / 179,4.5 \%)$, wearables supported the monitoring of an already diagnosed condition or a patient at risk (of deterioration).

\section{Others}

Studies $(14 / 179,7.8 \%)$ evaluated methods, with no other particular subgroup being appropriate.

\section{Strengths and Shortcomings of Wearables}

Overall, the studies mentioned more strengths than shortcomings. A few studies $(16 / 179,8.9 \%)$ mentioned no strengths of wearables, whereas $55.3 \%$ (99/179) of the studies mentioned no shortcomings.

Most often, authors (104/179, 58.1\%) emphasized the accuracy and reliability, positive results of peer-reviewed validation studies (own and of others), or clinically approved certifications (eg, the Food and Drug Administration [FDA] clearance in the United States or Communauté Européenne [CE] mark of the European Union; Figure 7). 
Figure 7. Chart of reported strengths and weaknesses of wearables as mentioned by authors. PA: physical activity.

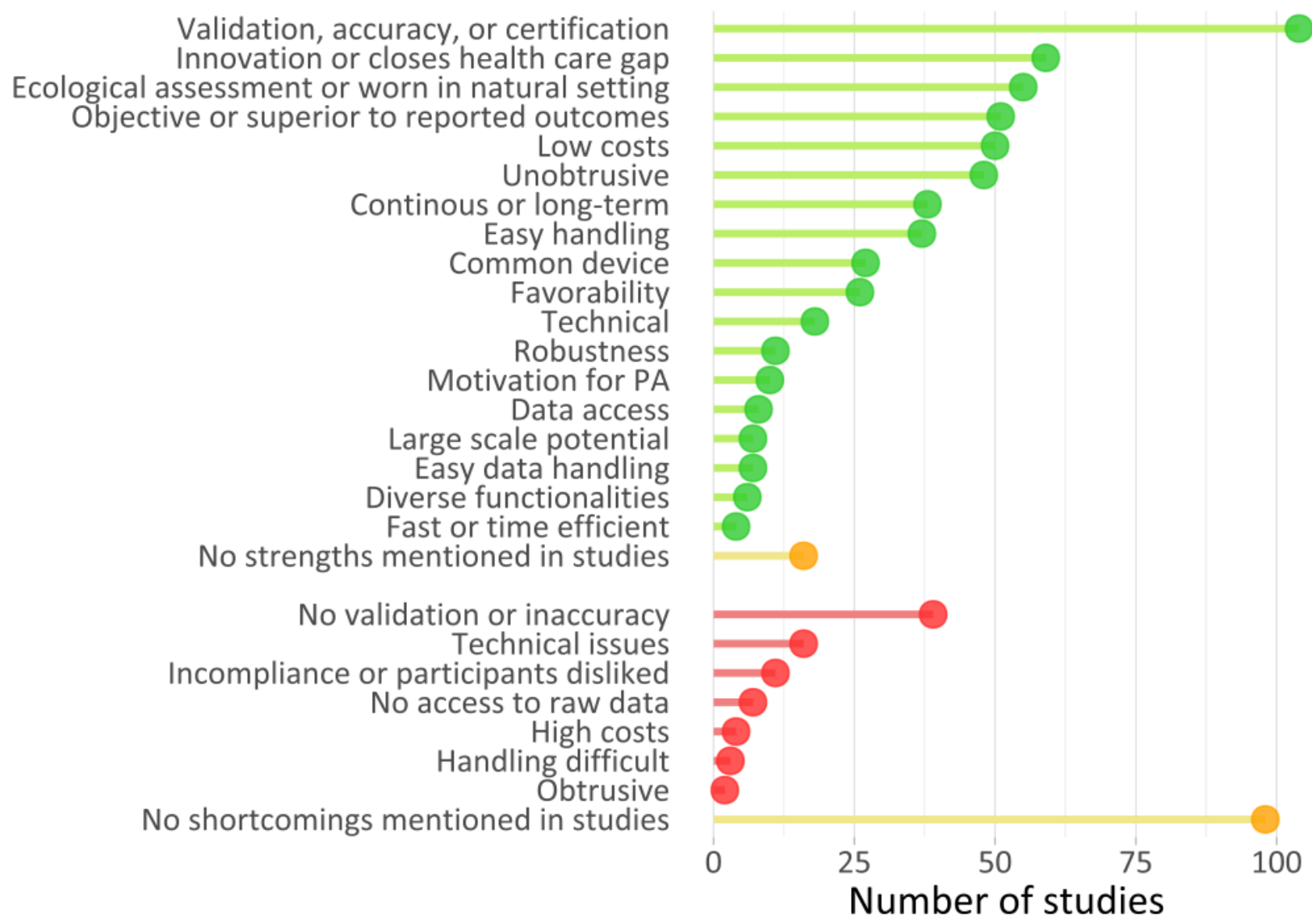

Often, studies $(59 / 179,33 \%)$ identified the wearable as innovative, that is, as a cutting-edge tool and method [103] with a wearable device potentially closing a gap in or improving health care and research. For example, 1 study described how wireless wearables and data synching could improve the quality of care [69], "The data can be sent from the wearable to the physician's office, avoiding the need for office visits, ultimately making possible preventive medicine and improving quality of care." Low et al [129] concluded that "Fitbit devices may provide opportunities to improve postoperative clinical care with minimal burden to patients or clinical providers." Tomitani et al [199] reflected how wrist-worn blood pressure wearables could "significantly improve blood pressure control." As per Shilaih et al [184], wrist-worn wearables might ameliorate fertility awareness research and care.

Several studies $(55 / 179,30.7 \%)$ acknowledged the ability of wearables to measure in the naturalistic environment of the participants, called ecological momentary assessment $[10,11,224]$.

Multiple studies $(51 / 179,28.5 \%)$ described wearables as objective and superior to self-reported outcomes as they were more accurate, reliable, and easier to generate. Often, the authors valued the relatively low costs of wearables $(50 / 179,27.9 \%)$. Others appreciated wearables as being unobtrusive or noninvasive $(48 / 179,26.8 \%)$ and enabling continuous, long-term measurements $(38 / 179,21.2 \%)$. Furthermore, the handling $(37 / 179,20.7 \%)$ of hardware and software was often found to be user-friendly, as well as the prevalence of wearables in the population $(27 / 179,15.1 \%)$, decreasing stigma and easing participant recruitment. Some studies $(26 / 179,14.5 \%)$ reported that participants accepted and liked the wearables, resulting in high participant compliance (wearing and using the wearable). Some authors $(18 / 179,10.1 \%)$ perceived technical wearable characteristics as positive, for example, good sampling rate of measurements, long battery life, large memory space, raw data availability, data security, compatibility with other devices such as smartphones, and availability of application programing interfaces (APIs).

Few studies $(11 / 179,6.1 \%)$ described wearables as robust and not easy to break. Authors $(10 / 179,5.6 \%)$ valued the wearable-induced behavior change as a cobenefit, that is, motivating study participants to more PA and increasing health awareness.

A few studies $(8 / 179,4.5 \%)$ mentioned data accessibility via APIs, apps, and web-based platforms and a few other studies $(7 / 179,3.9 \%)$ potential of large-scale wearable studies, or the ease of data handling. A few $(6 / 179,3.4 \%)$ studies underlined the variety of functionalities and vital sign measurements as positive aspects, and $2.2 \%$ (4/179) of studies perceived wearables as fast or time-efficient in data generation.

Most shortcomings $(39 / 179,21.8 \%)$ were related to the inaccuracy of the wearables or the absence of validation or clinically approved certification. Studies $(16 / 179,8.9 \%)$ also mentioned technical issues, such as a low sampling rate of measurements, no wear time recognition, or missing data. Other technical issues comprised, for example, synchronization, 
charging and device setup [91] or data cleaning [137]. Rare experienced shortcomings were participants' noncompliance or dislike toward the wearable $(11 / 179,6.1 \%)$, no access to raw data or company's algorithms $(4 / 179,2.2 \%)$, difficulties in handling the wearable $(3 / 179,1.7 \%)$, and wearables perceived as obtrusive in daily life $(2 / 179,1.1 \%)$.

\section{Discussion}

\section{Study Characteristics}

Overall, we have identified a positive trend in wearable studies, underlining the growing interest in wearables in health research, in line with other reviews [3,224-226]. Our results show a strong interest of researchers and study participants in this technology, but we also identified cautionary behavior toward using wearables. The vast majority of studies were undertaken in North America, about twice as many as in Europe, which is consistent with the previous literature [225]. One study in North America, conducted in 2019 with over 8 million participants [153], dominated the image of the distribution of participants. The reasons for the American-European gap may be multifaceted. One factor may be the differences in political and administrative frameworks, for example, comparing $\mathrm{CE}$ and FDA processes, which may result in slower certification processes for wearables and new technologies in general [31]. Another factor may be cultural mentality resulting in faster adoption of new technology in the United States, as the North Americans own proportionally more fitness trackers in comparison to the Europeans [227,228].

Some factors discussed in other research were not or only briefly mentioned in the included studies [6,29,31], but should also be reflected, especially technical and legal aspects, such as data security [224], data synching, and export. For example, the Germany-based study of Koehler et al [114] was one of the few that detailed data security and transfer of home-based telemonitoring data to the clinic. Data security and privacy are severely governed by the European Union General Data Protection Regulation, which is according to their website the "toughest privacy and security law in the world" [229]. Administrative limitations and challenges presumably obscure the benefits of wearable research in Europe. A possible solution for data security and usability might be data trusts [230] as an alternative to large platforms.

Most medical fields represented in the included studies showed similarities with other reviews [224], for example, studies often focusing on cardiology, sports medicine, and neurology. However, we found a multitude of studies from multidisciplinary fields as well as the field of global health, indicating a likely adoption and expansion of wearables in other medical fields. This underlines the potential for wearables in health research beyond a mere trend or hype, as wearables may provide new possibilities for a broad spectrum of health research, such as for infectious disease prediction like COVID-19 or fertility awareness, among many others.

\section{Wearable Characteristics}

Similar to other reviews, most devices were wrist-worn fitness trackers and accelerometers, and most of them are from the company Fitbit, measuring PA, HR, and sleep [3,27,31,224,225]. These vital signs and device types seem to become the standard in wearable research $[3,27,31,224,225]$. The included studies also emphasized the growing wearable use $[147,195,197]$, which is also reflected in commercially available devices [38-40]. Currently, further wearable devices emerge, measuring, for example, oximetry, blood pressure, skin temperature, or respiratory rate.

\section{Categorization of Wearable Application in the Studies}

In general, the included studies covered a great scope of health applications such as fertility tracking; monitoring of body characteristics such as weight or diseases such as Alzheimer disease, diabetes mellitus, and AF; as well as associations of coffee intake, sleep, and PA, or blood pressure and steps. We have noted an increase in smaller studies that also included rare populations and conditions, such as fibromyalgia or the rare genetic Pompe disease, indicating that wearables may be valuable for insights into patients with rare conditions. Using affordable, consumer-grade wearables for rare disease assessment and monitoring might eventually be less expensive than specifically developed devices and easier to use for patients. Therefore, currently underrepresented populations may be better researched through wearables [231], that is, different ethnic groups, nationalities, individuals with disabilities, or (rare) conditions. Future studies could examine the participation of underrepresented groups in wearable research in greater depth, particularly in studies analyzing wearable user data.

\section{Global Health and Low-Resource Contexts}

Included studies are predominantly from high-income countries, constituting a gap in wearable studies in low-resource contexts. The AliveCor device was shown to be feasible in Kenya to help detect AF [232], as well as for early diagnosis. The literature underlines the potential for wearable-based research in low-resource settings to generate data and improve health care [9], based on their low cost and ease of use (data acquisition, hardware, and software handling) [233]. Xu et al [234] emphasized that physiological monitoring with wearables hold "promise for substantial improvements in neonatal outcomes" in low- and middle-resource countries. Wearables can generate a solid database for global health research, particularly for morbidity measurements [235], large-scale studies, and modeling and descriptive studies. Topics such as climate change-induced impacts focusing on extreme weather events as an outcome and impact on health [236] may be approached. For example, 1 study [20] measured the physiological response of farm workers to climate conditions with wearables to investigate heat-related illness in a high-income setting. Lam et al [237] investigated the thermal adaptation and comfort of participants originating from various climatic regions. The fitness tracker measured HR data was integrated with other weather and human-based measurements and predicted the thermal sensation of nonlocal participants, among others. Similar studies can be conducted in low-resource regions.

\section{Strengths and Shortcomings of Wearables}

A few studies have experienced issues or shortcomings, such as inaccuracies in measurements and technical issues. 
Nevertheless, most authors were satisfied with wearables, as strengths were mentioned more frequently than shortcomings. Novelty and innovation outweighed the shortcomings for most authors. The most mentioned positive wearable characteristics were validity and accuracy, technical reliability, innovation, and unobtrusiveness. Only a few authors have mentioned data access through APIs or cloud platforms as a strength. However, the practical value of wearables is heavily reliant on the mode and reliability of data access. Depending on the company, there may be different data access policies in place, whereby it may not be possible to access the raw data of the wearable. Most authors have not considered wearable data access. However, data access and availability of wearable devices is an important aspect that researchers need to be aware of before using a potential study device. Another aspect is open access to the wearables' raw data or source codes, as companies might change the source code and implement algorithms without the obligation to announce or detail changes that might lead to bias and inconsistency of data [224]. For example, Thijs et al [195] mentioned the consequences of nondisclosed algorithms (Fitbit) for data analysis and standardization. Moreover, the lack of standardization and replicability of wearable raw data and analysis [28] hinders comparability among studies.

Most studies mentioned and discussed validation, accuracy, and certification of the used wearables as part of good research practice approaches. However, the mention of validation or accuracy did not necessarily imply that the wearables had been certified (FDA or CE) or validated in peer-reviewed research. Nevertheless, the authors reported that the wearable device is sufficiently accurate even with existing inaccuracies $[14,143,197]$. The authors seemed to tolerate smaller inaccuracies and validation drawbacks-especially of established consumer-grade wearables-if usability was of high importance, such as in large-scale studies.

\section{Large-scale and Big Data Sets for Wearable Research}

We noted an increase in large-scale wearable studies in recent years, which is consistent with previous literature [225]. During the COVID-19 pandemic, there has been an increase in studies using secondary data. Studies aimed at generating insights with regard to the developing pandemic, focusing on forecasting models and their effects on different populations. Overall, wearable-generated big data sets might decrease biased data because measurements are objectively taken in the natural environment of numerous and diverse individuals. Although data analytic skills are needed for handling big data sets, their analysis might be extremely valuable for health research in generating new evidence $[31,225]$.

\section{Limitations}

First, not all studies using wearables might have been identified by our search. We included only the wearables of companies in the search that had the highest market share. Therefore, the wearables of smaller or new companies may be missing in this review. In addition, we only included studies published in English, which may have excluded evidence from other regions that may not publish in English. Although this review provides a wide scope of wearable research, the list of included studies is by no means exhaustive.
In addition, wearable costs are only approximations and could be imprecise: (1) companies follow different sales and distribution models, for example membership, rental, and subscription; (2) we only incorporated wearable (hardware) prices, excluding costs for software, maintenance, and other charges such as subscription fees, which may even exceed wearable hardware costs; and (3) sales prices are subject to fluctuation. We also excluded many studies as wearables were discontinued. The fluctuant and unstable market, therefore, might also be a factor in decisions regarding the use of wearables [28]. Although interesting and promising, some wearables and similar devices were beyond the scope of this study but might also be valuable for health research. We have provided a wide overview of wearable devices; however, the included studies did not show the full range of possible wearables and measured vital signs [9,37].

In addition, we report the opinions of the included studies with regard to the shortcomings and strengths of wearables. Although these insights might be helpful, they are not objective measures. Moreover, our introduced categories for studies and aims to use wearables might overlap, as separation and categorization are artificial.

\section{Conclusions}

We see a growing uptake of wearables in health research and a trend to use wearables for large-scale, population-based studies. Wearables, which were often piloted in the included studies, were used in diverse health fields including COVID-19 prediction, fertility awareness, geriatrics, AF detection, evaluation of methods, drug effects, psychological interventions, and patient-reported outcomes. Measurement of steps, PA, HR, and sleep may be considered standard wearable measurements. Nevertheless, wearables are becoming more diverse in their measurements and appearance. Therefore, wearable-induced research may include currently underrepresented populations such as the older adults, participants who are disabled, participants with rare chronic or genetic diseases, participants from low socioeconomic backgrounds, and others.

For many researchers, novelty and innovation seem to outweigh shortcomings such as measurement inaccuracies. Overall, the included studies shared key characteristics that the wearables should meet: validity, technical reliability (including data access solutions), innovation, and unobtrusiveness.

We identified a lack of wearable research in low-resource settings. We assume that the reasons for the gap may be a lack of funding and doubts about the usefulness of the wearables. However, wearable devices may be used to generate data in such settings, which may otherwise be difficult and expensive to obtain. Therefore, wearable devices may be valuable for health research in a global context. During the COVID-19-pandemic in particular, large-sized wearable studies were used to generate insights into the developing pandemic and may potentially lead to novel insights into population health trends and forecasts. Future research is needed to determine the usability of wearable devices for underrepresented populations, as well as the feasibility and usefulness of health research in low-resource contexts. 


\section{Acknowledgments}

We wish to thank the German Research Foundation (Deutsche Forschungsgemeinschaft) for supporting this study as part of a Deutsche Forschungsgemeinschaft-funded research unit (Forschungsgruppe). We acknowledge the support of Else Kröner-Fresenius-Stiftung from the Heidelberg Graduate School of Global Health. Funders did not have a role in the design, data collection and analysis, decision to publish, or preparation of the manuscript.

\section{Authors' Contributions}

SH, SB, and MA conceived and designed the study. SH drafted the manuscript with the help of SB and MA. All authors contributed to the critical revision of the draft and approved the final version of the manuscript.

\section{Conflicts of Interest}

None declared.

\section{Multimedia Appendix 1}

PRISMA-ScR (Preferred Reporting Items for Systematic Reviews and Meta-Analyses extension for Scoping Reviews) checklist. [DOCX File, 116 KB-Multimedia Appendix 1]

\section{Multimedia Appendix 2}

Details on search and search strings.

[DOCX File, 16 KB-Multimedia Appendix 2]

\section{Multimedia Appendix 3}

Medical Education Research Study Quality Instrument scores of included studies.

[DOCX File , 62 KB-Multimedia Appendix 3]

\section{Multimedia Appendix 4}

Vital signs measured by studies.

[DOCX File, 254 KB-Multimedia Appendix 4]

\section{Multimedia Appendix 5}

Categorization of wearable applications in the studies: article references and examples.

[DOCX File , 65 KB-Multimedia Appendix 5]

\section{References}

1. Wearable band shipments rocket by $684 \%$. Canalys. Singapore; 2014 . URL: https://www.canalys.com/newsroom/ wearable-band-shipments-rocket-684?time=1605182466 [accessed 2020-11-12]

2. Henriksen A, Haugen Mikalsen M, Woldaregay AZ, Muzny M, Hartvigsen G, Hopstock LA, et al. Using fitness trackers and smartwatches to measure physical activity in research: analysis of consumer wrist-worn wearables. J Med Internet Res 2018;20(3):e110 [FREE Full text] [doi: 10.2196/jmir.9157] [Medline: 29567635]

3. Shin G, Jarrahi MH, Fei Y, Karami A, Gafinowitz N, Byun A, et al. Wearable activity trackers, accuracy, adoption, acceptance and health impact: a systematic literature review. J Biomed Inform 2019;93:103153. [doi: 10.1016/j.jbi.2019.103153] [Medline: 30910623]

4. Carpenter A, Frontera A. Smart-watches: a potential challenger to the implantable loop recorder. Europace 2016;18(6):791-793. [doi: 10.1093/europace/euv427] [Medline: 26847074]

5. Jia Y, Wang W, Wen D, Liang L, Gao L, Lei J. Perceived user preferences and usability evaluation of mainstream wearable devices for health monitoring. PeerJ 2018;6:e5350 [FREE Full text] [doi: 10.7717/peerj.5350] [Medline: $\underline{30065893]}$

6. Hickey AM, Freedson PS. Utility of consumer physical activity trackers as an intervention tool in cardiovascular disease prevention and treatment. Prog Cardiovasc Dis 2016;58(6):613-619. [doi: 10.1016/j.pcad.2016.02.006] [Medline: 26943981]

7. Fuller D, Colwell E, Low J, Orychock K, Tobin MA, Simango B, et al. Reliability and validity of commercially available wearable devices for measuring steps, energy expenditure, and heart rate: systematic review. JMIR Mhealth Uhealth 2020;8(9):e18694 [FREE Full text] [doi: 10.2196/18694] [Medline: 32897239]

8. Zhang Y, Weaver RG, Armstrong B, Burkart S, Zhang S, Beets MW. Validity of wrist-worn photoplethysmography devices to measure heart rate: a systematic review and meta-analysis. J Sports Sci 2020;38(17):2021-2034. [doi: 10.1080/02640414.2020.1767348] [Medline: 32552580] 
9. Dunn J, Runge R, Snyder M. Wearables and the medical revolution. Per Med 2018;15(5):429-448 [FREE Full text] [doi: 10.2217/pme-2018-0044] [Medline: 30259801]

10. Shiffman S, Stone AA, Hufford MR. Ecological momentary assessment. Annu Rev Clin Psychol 2008;4:1-32. [doi: 10.1146/annurev.clinpsy.3.022806.091415] [Medline: 18509902]

11. Zapata-Lamana R, Lalanza JF, Losilla JM, Parrado E, Capdevila L. mHealth technology for ecological momentary assessment in physical activity research: a systematic review. PeerJ 2020;8:e8848 [FREE Full text] [doi: 10.7717/peerj.8848] [Medline: 32257648]

12. Berrut G. La montre connectée : un instrument de santé publique? Geriatr Psychol Neuropsychiatr Vieil 2020;18(1):5. [doi: 10.1684/pnv.2020.0847] [Medline: $\underline{\text { 32160985] }}$

13. Robert Koch Institute. Corona-Datenspende | Robert Koch-Institut. Corona Data Donation. 2020. URL: https:/ /corona-datenspende.de/ [accessed 2020-10-26]

14. Radin JM, Wineinger NE, Topol EJ, Steinhubl SR. Harnessing wearable device data to improve state-level real-time surveillance of influenza-like illness in the USA: a population-based study. Lancet Digit Health 2020;2(2):e85-e93 [FREE Full text] [doi: 10.1016/S2589-7500(19)30222-5] [Medline: 33334565]

15. Perez MV, Mahaffey KW, Hedlin H, Rumsfeld JS, Garcia A, Ferris T, Apple Heart Study Investigators. Large-scale assessment of a smartwatch to identify atrial fibrillation. N Engl J Med 2019;381(20):1909-1917. [doi:

10.1056/NEJMoa1901183] [Medline: 31722151]

16. Worsham C, Jena AB. Why doctors shouldn't dismiss the Apple watch's new ECG app. Harvard Business Review. 2018. URL: https://hbr.org/2018/10/why-doctors-shouldnt-dismiss-the-apple-watchs-new-ecg-app [accessed 2020-10-02]

17. Dörr M, Nohturfft V, Brasier N, Bosshard E, Djurdjevic A, Gross S, et al. Reply: watch out: the many limitations in smartwatch-driven AF detection. JACC Clin Electrophysiol 2019;5(4):526-527 [FREE Full text] [doi:

10.1016/j.jacep.2019.03.001] [Medline: 31000111 ]

18. Kaneshiro M, Kaiser W, Pourmorady J, Fleshner P, Russell M, Zaghiyan K, et al. Postoperative gastrointestinal telemetry with an acoustic biosensor predicts ileus vs. uneventful GI recovery. J Gastrointest Surg 2016;20(1):132-139. [doi: 10.1007/s11605-015-2956-3] [Medline: 26408329]

19. Barajas-Carmona JG, Francisco-Aldana L, Morales-Narváez E. Wearable nanoplasmonic patch detecting Sun/UV exposure. Anal Chem 2017;89(24):13589-13595. [doi: 10.1021/acs.analchem.7b04066] [Medline: 29155557]

20. Culp K, Tonelli S. Heat-related illness in midwestern hispanic farmworkers: a descriptive analysis of hydration status and reported symptoms. Workplace Health Saf 2019;67(4):168-178 [FREE Full text] [doi: 10.1177/2165079918813380] [Medline: $\underline{30724664]}$

21. Choi DH, Thaxton A, Jeong IC, Kim K, Sosnay PR, Cutting GR, et al. Sweat test for cystic fibrosis: wearable sweat sensor vs. standard laboratory test. J Cyst Fibros 2018;17(4):e35-e38 [FREE Full text] [doi: 10.1016/j.jcf.2018.03.005] [Medline: 29580829]

22. Relf R, Willmott A, Flint MS, Beale L, Maxwell N. Reliability of a wearable sweat rate monitor and routine sweat analysis techniques under heat stress in females. J Therm Biol 2019;79:209-217. [doi: 10.1016/j.jtherbio.2018.12.019] [Medline: 30612681]

23. Kwon S, Hong J, Choi EK, Lee B, Baik C, Lee E, et al. Detection of atrial fibrillation using a ring-type wearable device (CardioTracker) and deep learning analysis of photoplethysmography signals: prospective observational proof-of-concept study. J Med Internet Res 2020;22(5):e16443 [FREE Full text] [doi: 10.2196/16443] [Medline: 32348254]

24. Genbrugge C, Eertmans W, Salcido DD. Monitor the quality of cardiopulmonary resuscitation in 2020. Curr Opin Crit Care 2020;26(3):219-227. [doi: 10.1097/MCC.0000000000000726] [Medline: 32332284]

25. Caduff A, Zanon M, Zakharov P, Mueller M, Talary M, Krebs A, et al. First experiences with a wearable multisensor in an outpatient glucose monitoring study, part I: the users' view. J Diabetes Sci Technol 2018;12(3):562-568 [FREE Full text] [doi: 10.1177/1932296817750932] [Medline: 29332423]

26. van der Kamp MR, Klaver EC, Thio BJ, Driessen JM, de Jongh FH, Tabak M, et al. WEARCON: wearable home monitoring in children with asthma reveals a strong association with hospital based assessment of asthma control. BMC Med Inform Decis Mak 2020;20(1):192 [FREE Full text] [doi: 10.1186/s12911-020-01210-1] [Medline: 32795352]

27. Foster KR, Torous J. The opportunity and obstacles for smartwatches and wearable sensors. IEEE Pulse 2019;10(1):22-25. [doi: 10.1109/MPULS.2018.2885832] [Medline: 30872210]

28. Shelgikar AV, Anderson PF, Stephens MR. Sleep tracking, wearable technology, and opportunities for research and clinical care. Chest 2016;150(3):732-743. [doi: 10.1016/j.chest.2016.04.016] [Medline: 27132701]

29. Jin D, Adams H, Cocco AM, Martin WG, Palmer S. Smartphones and wearable technology: benefits and concerns in cardiology. Med J Aust 2020;212(2):54-6.e1. [doi: 10.5694/mja2.50446] [Medline: 31851375]

30. Haberlin C, O'Dwyer T, Mockler D, Moran J, O'Donnell DM, Broderick J. The use of eHealth to promote physical activity in cancer survivors: a systematic review. Support Care Cancer 2018;26(10):3323-3336. [doi: 10.1007/s00520-018-4305-z] [Medline: 29909476]

31. Jacobsen M, Dembek TA, Kobbe G, Gaidzik PW, Heinemann L. Noninvasive continuous monitoring of vital signs with wearables: fit for medical use? J Diabetes Sci Technol 2021;15(1):34-43 [FREE Full text] [doi: 10.1177/1932296820904947] [Medline: $\underline{\text { 32063034] }}$ 
32. Tricco AC, Lillie E, Zarin W, O'Brien KK, Colquhoun H, Levac D, et al. PRISMA extension for scoping reviews (PRISMA-ScR): checklist and explanation. Ann Intern Med 2018;169(7):467-473. [doi: 10.7326/M18-0850] [Medline: $\underline{30178033}$

33. Arksey H, O'Malley L. Scoping studies: towards a methodological framework. Int J Soc Res Methodol 2005;8(1):19-32. [doi: 10.1080/1364557032000119616]

34. Peters MD, Godfrey CM, Khalil H, McInerney P, Parker D, Soares CB. Guidance for conducting systematic scoping reviews. Int J Evid Based Healthc 2015;13(3):141-146. [doi: 10.1097/XEB.0000000000000050] [Medline: 26134548]

35. Elliott M, Coventry A. Critical care: the eight vital signs of patient monitoring. Br J Nurs 2012;21(10):621-625. [doi: 10.12968/bjon.2012.21.10.621] [Medline: 22875303]

36. Dias D, Paulo Silva Cunha J. Wearable health devices-vital sign monitoring, systems and technologies. Sensors (Basel) 2018;18(8):2414 [FREE Full text] [doi: 10.3390/s18082414] [Medline: $\underline{\text { 30044415] }}$

37. Kamišalić A, Fister Jr I, Turkanović M, Karakatič S. Sensors and functionalities of non-invasive wrist-wearable devices: a review. Sensors (Basel) 2018;18(6):1714 [FREE Full text] [doi: 10.3390/s18061714] [Medline: 29799504]

38. Fortune Business Insights. Fitness tracker market to reach USD 91.98 billion by 2027; rising health disorders to brighten market prospects, states fortune business insights ${ }^{\mathrm{TM}}$. GlobeNewswire. 2020. URL: https://www.globenewswire.com/ news-release/2020/08/03/2071561/0/en/Fitness-Tracker-Market-to-Reach-USD-91-98-Billion-by-2027-

Rising-Health-Disorders- to-Brighten-Market-Prospects-states-Fortune-Business-Insights.html [accessed 2021-07-13]

39. International Data Corporation. Wearable devices market share. IDC Corporate USA. 2021. URL: https://www.idc.com/ promo/wearablevendor/vendor [accessed 2021-07-13]

40. Vailshery LS. Wearables shipments worldwide market share 2014-2021, by vendor. Statista. 2021. URL: https://www. statista.com/statistics/435944/quarterly-wearables-shipments-worldwide-market-share-by-vendor/ [accessed 2021-07-13]

41. Covidence systematic review software. Covidence. Melbourne: Veritas Health Innovation URL: https://www.covidence.org/ [accessed 2021-03-15]

42. Zotero. Roy Rosenzweig Center for History and New Media. Fairfax: Roy Rosenzweig Center for History and New Media URL: https://www.zotero.org/download/ [accessed 2021-03-15]

43. Cook DA, Reed DA. Appraising the quality of medical education research methods: the medical education research study quality instrument and the newcastle-ottawa scale-education. Acad Med 2015;90(8):1067-1076. [doi:

10.1097/ACM.0000000000000786] [Medline: 26107881]

44. Agarwal DK, Viers BR, Rivera ME, Nienow DA, Frank I, Tollefson MK, et al. Physical activity monitors can be successfully implemented to assess perioperative activity in urologic surgery. Mhealth 2018;4:43 [FREE Full text] [doi: 10.21037/mhealth.2018.09.05] [Medline: 30363722]

45. Alghamdi AS, Alghamdi KA, Jenkins RO, Alghamdi MN, Haris PI. Impact of Ramadan on physical activity and sleeping patterns in individuals with type 2 diabetes: the first study using fitbit device. Diabetes Ther 2020;11(6):1331-1346 [FREE Full text] [doi: 10.1007/s13300-020-00825-x] [Medline: 32367477]

46. An KH, Han KA, Sohn TS, Park IB, Kim HJ, Moon SD, et al. Body fat is related to sedentary behavior and light physical activity but not to moderate-vigorous physical activity in type 2 diabetes mellitus. Diabetes Metab J 2020;44(2):316-325 [FREE Full text] [doi: 10.4093/dmj.2019.0029] [Medline: 31769237]

47. Arigo D, Pasko K, Mogle JA. Daily relations between social perceptions and physical activity among college women. Psychol Sport Exerc 2020;47:101528 [FREE Full text] [doi: 10.1016/j.psychsport.2019.04.018] [Medline: 32831642]

48. Bade BC, Brooks MC, Nietert SB, Ulmer A, Thomas DD, Nietert PJ, et al. Assessing the correlation between physical activity and quality of life in advanced lung cancer. Integr Cancer Ther 2018;17(1):73-79 [FREE Full text] [doi: 10.1177/1534735416684016] [Medline: 28024420]

49. Baril JF, Bromberg S, Moayedi Y, Taati B, Manlhiot C, Ross HJ, et al. Use of free-living step count monitoring for heart failure functional classification: validation study. JMIR Cardio 2019;3(1):e12122 [FREE Full text] [doi: 10.2196/12122] [Medline: $\underline{31758777]}$

50. Barkley R, Khalil M, Shen P, Levine EA, Votanopoulos K, Clark CJ. Feasibility of low-cost accelerometers in measuring functional recovery after major oncologic surgery. J Surg Oncol 2019;121(2):279-285. [doi: 10.1002/jso.25789] [Medline: $\underline{31782174]}$

51. Barrett PM, Komatireddy R, Haaser S, Topol S, Sheard J, Encinas J, et al. Comparison of 24-hour Holter monitoring with 14-day novel adhesive patch electrocardiographic monitoring. Am J Med 2014;127(1):95.e11-95.e17 [FREE Full text] [doi: 10.1016/j.amjmed.2013.10.003] [Medline: 24384108]

52. Bevier W, Glantz N, Hoppe C, Morales Glass J, Larez A, Chen K, et al. Self-reported and objectively measured physical activity levels among Hispanic/Latino adults with type 2 diabetes. BMJ Open Diabetes Res Care 2020;8(1):e000893 [FREE Full text] [doi: 10.1136/bmjdrc-2019-000893] [Medline: $\underline{32169933]}$

53. Bian J, Guo Y, Xie M, Parish AE, Wardlaw I, Brown R, et al. Exploring the association between self-reported asthma impact and fitbit-derived sleep quality and physical activity measures in adolescents. JMIR Mhealth Uhealth 2017;5(7):e105 [FREE Full text] [doi: 10.2196/mhealth.7346] [Medline: 28743679] 
54. Billeci L, Tonacci A, Narzisi A, Manigrasso Z, Varanini M, Fulceri F, et al. Heart rate variability during a joint attention task in toddlers with autism spectrum disorders. Front Physiol 2018;9:467 [FREE Full text] [doi: 10.3389/fphys.2018.00467] [Medline: 29765335]

55. Birkeland K, Khandwalla RM, Kedan I, Shufelt CL, Mehta PK, Minissian MB, et al. Daily activity measured with wearable technology as a novel measurement of treatment effect in patients with coronary microvascular dysfunction: substudy of a randomized controlled crossover trial. JMIR Res Protoc 2017;6(12):e255 [FREE Full text] [doi: 10.2196/resprot.8057] [Medline: 29263019]

56. Blackshear TB, Seyfried L. Does education close the black-white physical activity and obesity gaps? J Am Coll Health 2021;69(2):222-226. [doi: 10.1080/07448481.2019.1657122] [Medline: 31765289]

57. Block VJ, Bove R, Zhao C, Garcha P, Graves J, Romeo AR, et al. Association of continuous assessment of step count by remote monitoring with disability progression among adults with multiple sclerosis. JAMA Netw Open 2019;2(3):e190570 [FREE Full text] [doi: 10.1001/jamanetworkopen.2019.0570] [Medline: 30874777]

58. Block VJ, Lizée A, Crabtree-Hartman E, Bevan CJ, Graves JS, Bove R, et al. Continuous daily assessment of multiple sclerosis disability using remote step count monitoring. J Neurol 2017;264(2):316-326. [doi: 10.1007/s00415-016-8334-6] [Medline: 27896433]

59. Bolourchi M, Batra AS. Diagnostic yield of patch ambulatory electrocardiogram monitoring in children (from a national registry). Am J Cardiol 2015;115(5):630-634. [doi: 10.1016/j.amjcard.2014.12.014] [Medline: 25591894]

60. Alvarez MP, Silva TD, Favero FM, Valenti VE, Raimundo RD, Vanderlei LC, et al. Autonomic modulation in Duchenne muscular dystrophy during a computer task: a prospective control trial. PLoS One 2017;12(1):e0169633 [FREE Full text] [doi: 10.1371/journal.pone.0169633] [Medline: 28118369]

61. Brazendale K, Brazendale AB, Garcia JM, Monroe CM, Weaver RG, Beets MW. Brief report: obesogenic behaviors of children with developmental disabilities during summer. J Autism Dev Disord 2021;51(2):734-740. [doi:

10.1007/s10803-020-04566-5] [Medline: 32533383]

62. Brudy L, Hock J, Häcker AL, Meyer M, Oberhoffer R, Hager A, et al. Children with congenital heart disease are active but need to keep moving: a cross-sectional study using wrist-worn physical activity trackers. J Pediatr 2020;217:13-19. [doi: 10.1016/j.jpeds.2019.09.077] [Medline: 31740142]

63. Buchan DS, McLellan G, Donnelly S, Arthur R. The use of the intensity gradient and average acceleration metrics to explore associations with BMI z-score in children. J Sports Sci 2019;37(23):2751-2758. [doi: 10.1080/02640414.2019.1664536] [Medline: $\underline{\text { 31506039] }}$

64. Burnett-Zeigler IE, Waldron EM, Hong S, Yang A, Wisner KL, Ciolino JD. Accessibility and feasibility of using technology to support mindfulness practice, reduce stress and promote long term mental health. Complement Ther Clin Pract 2018;33:93-99. [doi: 10.1016/j.ctcp.2018.09.001] [Medline: 30396633]

65. Cai M, Tan KH, Ang SB. I-ACT: integrated study on effect of activity on complications in pregnancy: study protocol of a multiethnic prospective cohort study. BMJ Open 2019;9(4):e025970 [FREE Full text] [doi: 10.1136/bmjopen-2018-025970] [Medline: 30948592]

66. Carrasco JJ, Pérez-Alenda S, Casaña J, Soria-Olivas E, Bonanad S, Querol F. Physical activity monitoring and acceptance of a commercial activity tracker in adult patients with haemophilia. Int J Environ Res Public Health 2019;16(20):3851 [FREE Full text] [doi: 10.3390/ijerph16203851] [Medline: $\underline{\text { 31614706] }}$

67. Cascino TM, McLaughlin VV, Richardson CR, Behbahani-Nejad N, Moles VM, Visovatti SH, et al. Barriers to physical activity in patients with pulmonary hypertension. Pulm Circ 2019;9(2):2045894019847895 [FREE Full text] [doi:

10.1177/2045894019847895] [Medline: 30983524]

68. Chang YT. Physical activity and cognitive function in mild cognitive impairment. ASN Neuro 2020;12:1759091419901182 [FREE Full text] [doi: 10.1177/1759091419901182] [Medline: 31948261]

69. Chapple C, Bliwise D, Maislisch L, Roitmann E, Burtea T. Night-time voids, level of bother and sleep characteristics in a non-patient population of wearable devices users. Int J Clin Pract 2020;74(7):e13495 [FREE Full text] [doi:

10.1111/ijcp.13495] [Medline: 32100396]

70. Chue AE, Gunthert KC, Kim RW, Alfano CA, Ruggiero AR. The role of sleep in adolescents' daily stress recovery: negative affect spillover and positive affect bounce-back effects. J Adolesc 2018;66:101-111. [doi: 10.1016/j.adolescence.2018.05.006] [Medline: 29842996]

71. Cohen-Holzer M, Sorek G, Schweizer M, Katz-Leurer M. The influence of a constraint and bimanual training program using a variety of modalities on endurance and on the cardiac autonomic regulation system of children with unilateral cerebral palsy: a self-control clinical trial. NeuroRehabilitation 2017;41(1):119-126. [doi: 10.3233/NRE-171463] [Medline: 28505992]

72. Cole TS, Jahnke H, Godzik J, Morgan CD, Nakaji P, Little AS. Use of a wrist-mounted device for continuous outpatient physiologic monitoring after transsphenoidal surgery: a pilot study. Pituitary 2019;22(2):156-162. [doi: 10.1007/s11102-019-00946-y] [Medline: 30806859]

73. Collier E, Varon C, Van Huffel S, Bogaert G. Enuretic children have a higher variability in REM sleep when comparing their sleep parameters with nonenuretic control children using a wearable sleep tracker at home. Neurourol Urodyn 2020;39(1):367-375. [doi: 10.1002/nau.24215] [Medline: $\underline{\text { 31729062] }}$ 
74. Costa J, Figueiredo P, Nakamura F, Rago V, Rebelo A, Brito J. Intra-individual variability of sleep and nocturnal cardiac autonomic activity in elite female soccer players during an international tournament. PLoS One 2019;14(9):e0218635 [FREE Full text] [doi: 10.1371/journal.pone.0218635] [Medline: $\underline{31527865}$ ]

75. Currow D, Watts GJ, Johnson M, McDonald CF, Miners JO, Somogyi AA, Australian national Palliative Care Clinical Studies Collaborative (PaCCSC). A pragmatic, phase III, multisite, double-blind, placebo-controlled, parallel-arm, dose increment randomised trial of regular, low-dose extended-release morphine for chronic breathlessness: Breathlessness, Exertion And Morphine Sulfate (BEAMS) study protocol. BMJ Open 2017;7(7):e018100 [FREE Full text] [doi: 10.1136/bmjopen-2017-018100] [Medline: 28716797]

76. DasMahapatra P, Chiauzzi E, Bhalerao R, Rhodes J. Free-living physical activity monitoring in adult US patients with multiple sclerosis using a consumer wearable device. Digit Biomark 2018;2(1):47-63 [FREE Full text] [doi: 10.1159/000488040] [Medline: $\underline{\text { 32095756] }}$

77. Do J, Webster RJ, Longmuir PE, Ieradi S, Reddy D, Whiting S, et al. Physically active children with epilepsy have good objective sleep duration and efficiency despite subjective reports of fatigue and sleep problems. Epilepsy Behav 2020;104(Pt A):106853. [doi: 10.1016/j.yebeh.2019.106853] [Medline: $\underline{31958642]}$

78. Downey C, Randell R, Brown J, Jayne DG. Continuous versus intermittent vital signs monitoring using a wearable, wireless patch in patients admitted to surgical wards: pilot cluster randomized controlled trial. J Med Internet Res 2018;20(12):e10802 [FREE Full text] [doi: 10.2196/10802] [Medline: $\underline{30538086}$ ]

79. Driesman AS, Strauss EJ, Konda SR, Egol KA. Factors associated with orthopaedic resident burnout: a pilot study. J Am Acad Orthop Surg 2020;28(21):900-906. [doi: 10.5435/JAAOS-D-19-00648] [Medline: 32039922]

80. Elmagboul N, Coburn BW, Foster J, Mudano A, Melnick J, Bergman D, et al. Physical activity measured using wearable activity tracking devices associated with gout flares. Arthritis Res Ther 2020;22(1):181 [FREE Full text] [doi: 10.1186/s13075-020-02272-2] [Medline: 32746893]

81. English C, Healy GN, Coates A, Lewis L, Olds T, Bernhardt J. Sitting and activity time in people with stroke. Phys Ther 2016;96(2):193-201. [doi: 10.2522/ptj.20140522] [Medline: 26112254]

82. Eyre EL, Duncan MJ, Birch SL, Cox V, Blackett M. Physical activity patterns of ethnic children from low socio-economic environments within the UK. J Sports Sci 2015;33(3):232-242. [doi: 10.1080/02640414.2014.934706] [Medline: 24998418]

83. Fagherazzi G, El Fatouhi D, Bellicha A, El Gareh A, Affret A, Dow C, et al. An international study on the determinants of poor sleep amongst 15,000 users of connected devices. J Med Internet Res 2017;19(10):e363 [FREE Full text] [doi: 10.2196/jmir.7930] [Medline: 29061551]

84. Fairclough SJ, Taylor S, Rowlands AV, Boddy LM, Noonan RJ. Average acceleration and intensity gradient of primary school children and associations with indicators of health and well-being. J Sports Sci 2019;37(18):2159-2167. [doi: 10.1080/02640414.2019.1624313] [Medline: 31156048]

85. Faust L, Feldman K, Mattingly SM, Hachen D, V Chawla N. Deviations from normal bedtimes are associated with short-term increases in resting heart rate. NPJ Digit Med 2020;3:39 [FREE Full text] [doi: 10.1038/s41746-020-0250-6] [Medline: $\underline{32219180}$ ]

86. Flatt AA, Esco MR. Evaluating individual training adaptation with smartphone-derived heart rate variability in a collegiate female soccer team. J Strength Cond Res 2016;30(2):378-385. [doi: 10.1519/JSC.0000000000001095] [Medline: 26200192]

87. Frie K, Hartmann-Boyce J, Jebb S, Oke J, Aveyard P. Patterns in weight and physical activity tracking data preceding a stop in weight monitoring: observational analysis. J Med Internet Res 2020;22(3):e15790 [FREE Full text] [doi: 10.2196/15790] [Medline: 32181749]

88. Ghomrawi HM, Baumann LM, Kwon S, Hebal F, Hsiung G, Williams K, et al. Using accelerometers to characterize recovery after surgery in children. J Pediatr Surg 2018;53(8):1600-1605. [doi: 10.1016/j.jpedsurg.2017.09.016] [Medline: 29092769]

89. Girard MP, O'Shaughnessy J, Doucet C, Ruchat SM, Descarreaux M. Association between physical activity, weight loss, anxiety, and lumbopelvic pain in postpartum women. J Manipulative Physiol Ther 2020;43(6):655-666. [doi: 10.1016/j.jmpt.2019.11.008] [Medline: 32709518]

90. Gluck S, Summers MJ, Finnis ME, Andrawos A, Goddard TP, Hodgson CL, et al. An observational study investigating the use of patient-owned technology to quantify physical activity in survivors of critical illness. Aust Crit Care 2020;33(2):137-143. [doi: 10.1016/j.aucc.2019.01.009] [Medline: $\underline{30879879}$ ]

91. Green DR, Gerberich SG, Kim H, Ryan AD, McGovern PM, Church TR, et al. Janitor workload and occupational injuries. Am J Ind Med 2019;62(3):222-232. [doi: 10.1002/ajim.22940] [Medline: 30675912]

92. Gresham G, Hendifar AE, Spiegel B, Neeman E, Tuli R, Rimel BJ, et al. Wearable activity monitors to assess performance status and predict clinical outcomes in advanced cancer patients. NPJ Digit Med 2018;1:27 [FREE Full text] [doi: 10.1038/s41746-018-0032-6] [Medline: $\underline{\text { 31304309] }}$

93. Grimes L, Outtrim JG, Griffin SJ, Ercole A. Accelerometery as a measure of modifiable physical activity in high-risk elderly preoperative patients: a prospective observational pilot study. BMJ Open 2019;9(11):e032346 [FREE Full text] [doi: 10.1136/bmjopen-2019-032346] [Medline: 31685513]

94. Groat D, Kwon HJ, Grando MA, Cook CB, Thompson B. Comparing real-time self-tracking and device-recorded exercise data in subjects with type 1 diabetes. Appl Clin Inform 2018;9(4):919-926 [FREE Full text] [doi: 10.1055/s-0038-1676458] [Medline: $\underline{30586673}$ ] 
95. Guo Y, Wang H, Zhang H, Chen Y, Lip GY. Population-based screening or targeted screening based on initial clinical risk assessment for atrial fibrillation: a report from the Huawei heart study. J Clin Med 2020;9(5):1493 [FREE Full text] [doi: 10.3390/jcm9051493] [Medline: $\underline{\text { 32429241] }}$

96. Guo Y, Wang H, Zhang H, Liu T, Liang Z, Xia Y, MAFA II Investigators. Mobile photoplethysmographic technology to detect atrial fibrillation. J Am Coll Cardiol 2019;74(19):2365-2375. [doi: 10.1016/j.jacc.2019.08.019] [Medline: 31487545]

97. Hamed A, Curran C, Gwaltney C, DasMahapatra P. Mobility assessment using wearable technology in patients with late-onset Pompe disease. NPJ Digit Med 2019;2:70 [FREE Full text] [doi: 10.1038/s41746-019-0143-8] [Medline: 31341956]

98. Han M, Ye X, Preciado P, Williams S, Campos I, Bonner M, et al. Relationships between neighborhood walkability and objectively measured physical activity levels in hemodialysis patients. Blood Purif 2018;45(1-3):236-244 [FREE Full text] [doi: 10.1159/000485161] [Medline: 29478044]

99. Hemphill NM, Kuan MT, Harris KC. Reduced physical activity during COVID-19 pandemic in children with congenital heart disease. Can J Cardiol 2020;36(7):1130-1134 [FREE Full text] [doi: 10.1016/j.cjca.2020.04.038] [Medline: 32387502]

100. Hirschberg R, Sylvia LG, Wright EC, Gupta CT, McCarthy MD, Harward LK, et al. Collaborative songwriting intervention for veterans with post-traumatic stress disorder. J Altern Complement Med 2020;26(3):198-203. [doi: 10.1089/acm.2019.0368] [Medline: 31985263]

101. Huberty JL, Buman MP, Leiferman JA, Bushar J, Adams MA. Trajectories of objectively-measured physical activity and sedentary time over the course of pregnancy in women self-identified as inactive. Prev Med Rep 2016;3:353-360 [FREE Full text] [doi: 10.1016/j.pmedr.2016.04.004] [Medline: 27419036]

102. Jeong JN, Kim SH, Park KN. Relationship between objectively measured lifestyle factors and health factors in patients with knee osteoarthritis: the STROBE study. Medicine (Baltimore) 2019;98(26):e16060 [FREE Full text] [doi: 10.1097/MD.0000000000016060] [Medline: 31261513]

103. Jiang F, Kobayashi T, Ichihashi T, Ito K, Nomura S. The effect of citrus ginger aroma on heart rate and salivary cortisol level during sleep at home. IEEJ Trans Elec Electron Eng 2019;14(4):623-629. [doi: 10.1002/tee.22845]

104. John-Henderson NA, Palmer CA, Thomas A. Life stress, sense of belonging and sleep in American Indian college students. Sleep Health 2019;5(4):352-358 [FREE Full text] [doi: $\underline{10.1016 / j . s l e h .2019 .04 .001]}$ [Medline: $\underline{31153800]}$

105. Jones MA, Skidmore PM, Stoner L, Harrex H, Saeedi P, Black K, et al. Associations of accelerometer-measured sedentary time, sedentary bouts, and physical activity with adiposity and fitness in children. J Sports Sci 2020;38(1):114-120. [doi: 10.1080/02640414.2019.1685842] [Medline: $\underline{31665975}$ ]

106. Jonker LT, Hendriks S, Lahr MM, van Munster BC, de Bock GH, van Leeuwen BL. Postoperative recovery of accelerometer-based physical activity in older cancer patients. Eur J Surg Oncol 2020;46(11):2083-2090 [FREE Full text] [doi: 10.1016/j.ejso.2020.06.012] [Medline: $\underline{32682650}$ ]

107. Kabbach EZ, Mazzuco A, Borghi-Silva A, Cabiddu R, Agnoleto AG, Barbosa JF, et al. Increased parasympathetic cardiac modulation in patients with acute exacerbation of COPD: how should we interpret it? Int J Chron Obstruct Pulmon Dis 2017;12:2221-2230 [FREE Full text] [doi: 10.2147/COPD.S134498] [Medline: 28814850]

108. Kagamiyama H, Yano R. Relationship between subjective fatigue, physical activity, and sleep indices in nurses working 16-hour night shifts in a rotating two-shift system. J Rural Med 2018;13(1):26-32 [FREE Full text] [doi: 10.2185/jrm.2951] [Medline: 29875894]

109. Kaura A, Sztriha L, Chan FK, Aeron-Thomas J, Gall N, Piechowski-Jozwiak B, et al. Early prolonged ambulatory cardiac monitoring in stroke (EPACS): an open-label randomised controlled trial. Eur J Med Res 2019;24(1):25 [FREE Full text] [doi: 10.1186/s40001-019-0383-8] [Medline: 31349792]

110. Kim DH, Nam KH, Choi BK, Han IH, Jeon TJ, Park SY. The usefulness of a wearable device in daily physical activity monitoring for the hospitalized patients undergoing lumbar surgery. J Korean Neurosurg Soc 2019;62(5):561-566 [FREE Full text] [doi: 10.3340/jkns.2018.0131] [Medline: $\underline{31337197]}$

111. Kim Y, Wijndaele K, Sharp SJ, Strain T, Pearce M, White T, et al. Specific physical activities, sedentary behaviours and sleep as long-term predictors of accelerometer-measured physical activity in 91,648 adults: a prospective cohort study. Int J Behav Nutr Phys Act 2019;16(1):41 [FREE Full text] [doi: 10.1186/s12966-019-0802-9] [Medline: $\underline{31064403}$ ]

112. Kimura N, Aso Y, Yabuuchi K, Ishibashi M, Hori D, Sasaki Y, et al. Association of modifiable lifestyle factors with cortical amyloid burden and cerebral glucose metabolism in older adults with mild cognitive impairment. JAMA Netw Open 2020;3(6):e205719 [FREE Full text] [doi: 10.1001/jamanetworkopen.2020.5719] [Medline: $\underline{32515796}$ ]

113. Kochiya Y, Hirabayashi A, Ichimaru Y. Nocturnal heart rate variability in 1-year-old infants analyzed by using the least square cosine spectrum method. J Physiol Anthropol 2017;36(1):36 [FREE Full text] [doi: 10.1186/s40101-017-0152-8] [Medline: 28915915]

114. Koehler F, Koehler K, Deckwart O, Prescher S, Wegscheider K, Kirwan BA, et al. Efficacy of telemedical interventional management in patients with heart failure (TIM-HF2): a randomised, controlled, parallel-group, unmasked trial. Lancet 2018;392(10152):1047-1057 [FREE Full text] [doi: 10.1016/S0140-6736(18)31880-4] [Medline: 30153985]

115. Kolk D, Aarden JJ, MacNeil-Vroomen JL, Reichardt LA, van Seben R, van der Schaaf M, Hospital-ADL Study Group. Factors associated with step numbers in acutely hospitalized older adults: the hospital-activities of daily living study. $\mathrm{J}$ Am Med Dir Assoc 2021;22(2):425-432 [FREE Full text] [doi: 10.1016/j.jamda.2020.06.027] [Medline: $\underline{32713773]}$ 
116. Kruizinga MD, Zuiker RG, Sali E, de Kam ML, Doll RJ, Groeneveld GJ, et al. Finding suitable clinical endpoints for a potential treatment of a rare genetic disease: the case of ARID1B. Neurotherapeutics 2020;17(3):1300-1310 [FREE Full text] [doi: 10.1007/s13311-020-00868-9] [Medline: 32462407]

117. Lamar DL, Chou SH, Medverd JR, Swanson JO. Sedentary behavior in the workplace: a potential occupational hazard for radiologists. Curr Probl Diagn Radiol 2016;45(4):253-257. [doi: 10.1067/j.cpradiol.2015.10.007] [Medline: 26675263]

118. Larsen SC, Horgan G, Mikkelsen MK, Palmeira AL, Scott S, Duarte C, et al. Consistent sleep onset and maintenance of body weight after weight loss: an analysis of data from the NoHoW trial. PLoS Med 2020;17(7):e1003168 [FREE Full text] [doi: 10.1371/journal.pmed.1003168] [Medline: 32673309]

119. Lazaridou A, Paschali M, Schreiber K, Galenkamp L, Berry M, Paschalis T, et al. The association between daily physical exercise and pain among women with fibromyalgia: the moderating role of pain catastrophizing. Pain Rep 2020;5(4):e832 [FREE Full text] [doi: 10.1097/PR9.0000000000000832] [Medline: 32766468]

120. Le Hello C, Trombert B, Morel A, Chieh A, Brouard B, Boissier C. Performance analysis of walking of 10,000 regular users of a connected activity tracker. J Med Vasc 2018;43(4):231-237. [doi: 10.1016/j.jdmv.2018.04.001] [Medline: 29981731]

121. Lee JE, Lee DH, Oh TJ, Kim KM, Choi SH, Lim S, et al. Clinical feasibility of continuously monitored data for heart rate, physical activity, and sleeping by wearable activity trackers in patients with thyrotoxicosis: protocol for a prospective longitudinal observational study. JMIR Res Protoc 2018;7(2):e49 [FREE Full text] [doi: 10.2196/resprot.8119] [Medline: 29467121]

122. Lee JP, Chen S, Tsai CT, Chung HC, Chang WD. Characteristics associated with the differential activity of nondominant and dominant affected hands in patients with poststroke right hemiparesis. Occup Ther Int 2020;2020:2387378 [FREE Full text] [doi: 10.1155/2020/2387378] [Medline: 32565757]

123. Lee KM, Rogers MP, Galbarczyk A, Jasienska G, Clancy KB. Physical activity in women of reproductive age in a transitioning rural polish population. Am J Hum Biol 2019;31(3):e23231. [doi: 10.1002/ajhb.23231] [Medline: 30835924$]$

124. Liao Y, Robertson MC, Winne A, Wu IH, Le TA, Balachandran DD, et al. Investigating the within-person relationships between activity levels and sleep duration using Fitbit data. Transl Behav Med 2021;11(2):619-624. [doi: 10.1093/tbm/ibaa071] [Medline: 32667039 ]

125. Lim SE, Dodds R, Bacon D, Sayer AA, Roberts HC. Physical activity among hospitalised older people: insights from upper and lower limb accelerometry. Aging Clin Exp Res 2018;30(11):1363-1369 [FREE Full text] [doi: 10.1007/s40520-018-0930-0] [Medline: 29542070]

126. Lim WK, Davila S, Teo JX, Yang C, Pua CJ, Blöcker C, et al. Beyond fitness tracking: the use of consumer-grade wearable data from normal volunteers in cardiovascular and lipidomics research. PLoS Biol 2018;16(2):e2004285 [FREE Full text] [doi: 10.1371/journal.pbio.2004285] [Medline: 29485983]

127. Lin H, Sardana M, Zhang Y, Liu C, Trinquart L, Benjamin EJ, et al. Association of habitual physical activity with cardiovascular disease risk. Circ Res 2020;127(10):1253-1260. [doi: 10.1161/CIRCRESAHA.120.317578] [Medline: $\underline{32842915}$ ]

128. Liu S, Eaton CB, Driban JB, McAlindon TE, Lapane KL. Comparison of self-report and objective measures of physical activity in US adults with osteoarthritis. Rheumatol Int 2016;36(10):1355-1364. [doi: 10.1007/s00296-016-3537-9] [Medline: $\underline{27435920]}$

129. Low CA, Bovbjerg DH, Ahrendt S, Choudry MH, Holtzman M, Jones HL, et al. Fitbit step counts during inpatient recovery from cancer surgery as a predictor of readmission. Ann Behav Med 2018;52(1):88-92 [FREE Full text] [doi: 10.1093/abm/kax022] [Medline: 29538623]

130. Low CA, Dey AK, Ferreira D, Kamarck T, Sun W, Bae S, et al. Estimation of symptom severity during chemotherapy from passively sensed data: exploratory study. J Med Internet Res 2017;19(12):e420 [FREE Full text] [doi: 10.2196/jmir.9046] [Medline: 29258977]

131. Ma J, Martin R, Chan B, Gofeld M, Geary MP, Laffey JG, et al. Using activity trackers to quantify postpartum ambulation: a prospective observational study of ambulation after regional anesthesia and analgesia interventions. Anesthesiology 2018;128(3):598-608 [FREE Full text] [doi: 10.1097/ALN.0000000000001979] [Medline: 29135475]

132. Maijala A, Kinnunen H, Koskimäki H, Jämsä T, Kangas M. Nocturnal finger skin temperature in menstrual cycle tracking: ambulatory pilot study using a wearable Oura ring. BMC Womens Health 2019;19(1):150 [FREE Full text] [doi: 10.1186/s12905-019-0844-9] [Medline: 31783840]

133. Makic MB, Gilbert D, Jankowski C, Reeder B, Al-Salmi N, Starr W, et al. Sensor and survey measures associated with daily fatigue in HIV: findings from a mixed-method study. J Assoc Nurses AIDS Care 2020;31(1):12-24. [doi: 10.1097/JNC.0000000000000152] [Medline: 31860594]

134. Massey WV, Stellino MB, Geldhof J. An observational study of recess quality and physical activity in urban primary schools. BMC Public Health 2020;20(1):792 [FREE Full text] [doi: 10.1186/s12889-020-08849-5] [Medline: 32460860]

135. Massey WV, Stellino MB, Fraser M. Individual and environmental correlates of school-based recess engagement. Prev Med Rep 2018;11:247-253 [FREE Full text] [doi: 10.1016/j.pmedr.2018.07.005] [Medline: 30094127] 
136. Matcham F, Barattieri di San Pietro C, Bulgari V, de Girolamo G, Dobson R, Eriksson H, RADAR-CNS consortium. Remote assessment of disease and relapse in major depressive disorder (RADAR-MDD): a multi-centre prospective cohort study protocol. BMC Psychiatry 2019;19(1):72 [FREE Full text] [doi: 10.1186/s12888-019-2049-z] [Medline: $\underline{30777041]}$

137. McLean DC, Nakamura J, Csikszentmihalyi M. Reconsidering the experience machine: self-reported versus objective measures of physical activity to increase positive affect. J Health Psychol 2020;25(13-14):2428-2439. [doi: 10.1177/1359105318801939] [Medline: 30246550]

138. Mead MP, Baron K, Sorby M, Irish LA. Daily associations between sleep and physical activity. Int J Behav Med 2019;26(5):562-568. [doi: 10.1007/s12529-019-09810-6] [Medline: 31372835]

139. Meijer K, Annegarn J, Lima Passos V, Savelberg HH, Schols AM, Wouters EF, et al. Characteristics of daily arm activities in patients with COPD. Eur Respir J 2014;43(6):1631-1641 [FREE Full text] [doi: 10.1183/09031936.00082513] [Medline: 24558175]

140. Melin M, Hagerman I, Gonon A, Gustafsson T, Rullman E. Variability in physical activity assessed with accelerometer is an independent predictor of mortality in CHF patients. PLoS One 2016;11(4):e0153036 [FREE Full text] [doi: 10.1371/journal.pone.0153036] [Medline: 27054323]

141. Menai M, Brouard B, Vegreville M, Chieh A, Schmidt N, Oppert JM, et al. Cross-sectional and longitudinal associations of objectively-measured physical activity on blood pressure: evaluation in 37 countries. Health Promot Perspect 2017;7(4):190-196 [FREE Full text] [doi: 10.15171/hpp.2017.34] [Medline: 29085795]

142. Mendelsohn D, Despot I, Gooderham PA, Singhal A, Redekop GJ, Toyota BD. Impact of work hours and sleep on well-being and burnout for physicians-in-training: the Resident Activity Tracker Evaluation Study. Med Educ 2019;53(3):306-315. [doi: 10.1111/medu.13757] [Medline: $\underline{30485496]}$

143. Mičková E, Machová K, Dađ̌ová K, Svobodová I. Does dog ownership affect physical activity, sleep, and self-reported health in older adults? Int J Environ Res Public Health 2019;16(18):3355 [FREE Full text] [doi: 10.3390/ijerph16183355] [Medline: $\underline{31514379}$ ]

144. Miller DJ, Capodilupo JV, Lastella M, Sargent C, Roach GD, Lee VH, et al. Analyzing changes in respiratory rate to predict the risk of COVID-19 infection. PLoS One 2020;15(12):e0243693 [FREE Full text] [doi: 10.1371/journal.pone.0243693] [Medline: 33301493 ]

145. Mobbs RJ, Phan K, Maharaj M, Rao PJ. Physical activity measured with accelerometer and self-rated disability in lumbar spine surgery: a prospective study. Global Spine J 2016;6(5):459-464 [FREE Full text] [doi: 10.1055/s-0035-1565259] [Medline: 27433430]

146. Mocny-Pachońska K, Doniec R, Trzcionka A, Pachoński M, Piaseczna N, Sieciński S, et al. Evaluating the stress-response of dental students to the dental school environment. PeerJ 2020;8:e8981 [FREE Full text] [doi: 10.7717/peerj.8981] [Medline: $\underline{32411517]}$

147. Modarress-Sadeghi M, Oura P, Junno JA, Niemelä M, Niinimäki J, Jämsä T, et al. Objectively measured physical activity is associated with vertebral size in midlife. Med Sci Sports Exerc 2019;51(8):1606-1612. [doi: 10.1249/MSS.0000000000001962] [Medline: 30817715]

148. Mora-Gonzalez J, Migueles JH, Esteban-Cornejo I, Cadenas-Sanchez C, Pastor-Villaescusa B, Molina-García P, et al. Sedentarism, physical activity, steps, and neurotrophic factors in obese children. Med Sci Sports Exerc 2019;51(11):2325-2333. [doi: 10.1249/MSS.0000000000002064] [Medline: 31634295]

149. Morcos MW, Teeter MG, Somerville LE, Lanting B. Correlation between hip osteoarthritis and the level of physical activity as measured by wearable technology and patient-reported questionnaires. J Orthop 2019;20:236-239 [FREE Full text] [doi: 10.1016/j.jor.2019.11.049] [Medline: 32071522]

150. Morhardt DR, Luckenbaugh A, Goldstein C, Faerber GJ. Determining resident sleep during and after call with commercial sleep monitoring devices. Urology 2017;106:39-44. [doi: 10.1016/j.urology.2017.03.059] [Medline: 28502597]

151. Mueller C, Stollfuss B, Roitenberg A, Harder J, Richter MJ. Evaluation of clinical outcomes and simultaneous digital tracking of daily physical activity, heart rate, and inhalation behavior in patients with pulmonary arterial hypertension treated with inhaled iloprost: protocol for the observational VENTASTEP study. JMIR Res Protoc 2019;8(4):e12144 [FREE Full text] [doi: 10.2196/12144] [Medline: $\underline{30985279}$ ]

152. Murphree DH, Kinard TN, Khera N, Storlie CB, Ngufor C, Upadhyaya S, et al. Measuring the impact of ambulatory red blood cell transfusion on home functional status: study protocol for a pilot randomized controlled trial. Trials 2017;18(1):153 [FREE Full text] [doi: 10.1186/s13063-017-1873-z] [Medline: 28359342]

153. Natarajan A, Pantelopoulos A, Emir-Farinas H, Natarajan P. Heart rate variability with photoplethysmography in 8 million individuals: a cross-sectional study. Lancet Digit Health 2020;2(12):e650-e657. [doi: 10.1016/S2589-7500(20)30246-6] [Medline: 33328029]

154. Niemelä MS, Kangas M, Ahola RJ, Auvinen JP, Leinonen AM, Tammelin TH, et al. Dose-response relation of self-reported and accelerometer-measured physical activity to perceived health in middle age-the Northern Finland Birth Cohort 1966 Study. BMC Public Health 2019;19(1):21 [FREE Full text] [doi: 10.1186/s12889-018-6359-8] [Medline: $\underline{30612541]}$

155. Nishida M, Kikuchi S, Miwakeichi F, Suda S. Night duty and decreased brain activity of medical residents: a wearable optical topography study. Med Educ Online 2017;22(1):1379345 [FREE Full text] [doi: 10.1080/10872981.2017.1379345] [Medline: $\underline{28954586}$ ] 
156. Nowell WB, Curtis JR, Nolot SK, Curtis D, Venkatachalam S, Owensby JK, et al. Digital tracking of rheumatoid arthritis longitudinally (DIGITAL) using biosensor and patient-reported outcome data: protocol for a real-world study. JMIR Res Protoc 2019;8(9):e14665 [FREE Full text] [doi: 10.2196/14665] [Medline: $\underline{\text { 31573949] }}$

157. Orme MW, Steiner MC, Morgan MD, Kingsnorth AP, Esliger DW, Singh SJ, et al. 24-hour accelerometry in COPD: exploring physical activity, sedentary behavior, sleep and clinical characteristics. Int J Chron Obstruct Pulmon Dis 2019;14:419-430 [FREE Full text] [doi: 10.2147/COPD.S183029] [Medline: 30863042]

158. Otsuki T, Ishii N. Association between blood pressure changes during self-paced outdoor walking and air temperature. Clin Physiol Funct Imaging 2017;37(2):155-161. [doi: 10.1111/cpf.12280] [Medline: 26211639]

159. Pakhomov SV, Thuras PD, Finzel R, Eppel J, Kotlyar M. Using consumer-wearable technology for remote assessment of physiological response to stress in the naturalistic environment. PLoS One 2020;15(3):e0229942 [FREE Full text] [doi: 10.1371/journal.pone.0229942] [Medline: 32210441]

160. Pastor N, Khalilian E, Caballeria E, Morrison D, Sanchez Luque U, Matrai S, et al. Remote monitoring telemedicine (REMOTE) platform for patients with anxiety symptoms and alcohol use disorder: protocol for a case-control study. JMIR Res Protoc 2020;9(6):e16964 [FREE Full text] [doi: 10.2196/16964] [Medline: 32579124]

161. Peach HD, Gaultney JF, Ruggiero AR. Direct and indirect associations of sleep knowledge and attitudes with objective and subjective sleep duration and quality via sleep hygiene. J Prim Prev 2018;39(6):555-570. [doi:

10.1007/s10935-018-0526-7] [Medline: 30443688]

162. Pépin JL, Bruno RM, Yang RY, Vercamer V, Jouhaud P, Escourrou P, et al. Wearable activity trackers for monitoring adherence to home confinement during the COVID-19 pandemic worldwide: data aggregation and analysis. J Med Internet Res 2020;22(6):e19787 [FREE Full text] [doi: 10.2196/19787] [Medline: 32501803]

163. Phillips LJ, Petroski GF, Conn VS, Brown M, Leary E, Teri L, et al. Exploring path models of disablement in residential care and assisted living residents. J Appl Gerontol 2018;37(12):1490-1516 [FREE Full text] [doi: 10.1177/0733464816672048] [Medline: 27708073]

164. Pozehl BJ, Mcguire R, Duncan K, Hertzog M, Deka P, Norman J, et al. Accelerometer-measured daily activity levels and related factors in patients with heart failure. J Cardiovasc Nurs 2018;33(4):329-335 [FREE Full text] [doi: 10.1097/JCN.0000000000000464] [Medline: 29538050]

165. Pradhan S, Kelly VE. Quantifying physical activity in early Parkinson disease using a commercial activity monitor. Parkinsonism Relat Disord 2019;66:171-175 [FREE Full text] [doi: 10.1016/j.parkreldis.2019.08.001] [Medline: 31420310]

166. Quer G, Gouda P, Galarnyk M, Topol EJ, Steinhubl SR. Inter- and intraindividual variability in daily resting heart rate and its associations with age, sex, sleep, BMI, and time of year: retrospective, longitudinal cohort study of 92,457 adults. PLoS One 2020;15(2):e0227709 [FREE Full text] [doi: 10.1371/journal.pone.0227709] [Medline: 32023264 ]

167. Quer G, Radin JM, Gadaleta M, Baca-Motes K, Ariniello L, Ramos E, et al. Wearable sensor data and self-reported symptoms for COVID-19 detection. Nat Med 2021;27(1):73-77. [doi: 10.1038/s41591-020-1123-x] [Medline: 33122860]

168. Quiroz JC, Geangu E, Yong MH. Emotion recognition using smart watch sensor data: mixed-design study. JMIR Ment Health 2018;5(3):e10153 [FREE Full text] [doi: 10.2196/10153] [Medline: 30089610]

169. Rahman MJ, Morshed BI, Harmon B. A field study to capture events of interest (EoI) from living labs using wearables for spatiotemporal monitoring towards a framework of smart health (sHealth). Annu Int Conf IEEE Eng Med Biol Soc 2020;2020:5943-5947. [doi: 10.1109/EMBC44109.2020.9175771] [Medline: 33019327]

170. Rahman MJ, Nemati E, Rahman M, Vatanparvar K, Nathan V, Kuang J. Toward early severity assessment of obstructive lung disease using multi-modal wearable sensor data fusion during walking. Annu Int Conf IEEE Eng Med Biol Soc 2020;2020:5935-5938. [doi: 10.1109/EMBC44109.2020.9176559] [Medline: 33019325]

171. Ramirez E, Marinsek N, Bradshaw B, Kanard R, Foschini L. Continuous digital assessment for weight loss surgery patients. Digit Biomark 2020;4(1):13-20 [FREE Full text] [doi: 10.1159/000506417] [Medline: 32399512]

172. Raywood E, Douglas H, Kapoor K, Filipow N, Murray N, O'Connor R, et al. Protocol for Project Fizzyo, an analytic longitudinal observational cohort study of physiotherapy for children and young people with cystic fibrosis, with interrupted time-series design. BMJ Open 2020;10(10):e039587 [FREE Full text] [doi: 10.1136/bmjopen-2020-039587] [Medline: 33033031]

173. Reddy R, El Youssef J, Winters-Stone K, Branigan D, Leitschuh J, Castle J, et al. The effect of exercise on sleep in adults with type 1 diabetes. Diabetes Obes Metab 2018;20(2):443-447 [FREE Full text] [doi: 10.1111/dom.13065] [Medline: 28718987]

174. Roe J, Salmon L, Twiggs J. Objective measure of activity level after total knee arthoplasty with the use of the 'Fitbit' device. Orthop J Sports Med 2016;4(Supplement 2):2325967116S00012 [FREE Full text] [doi: 10.1177/2325967116S00012]

175. Root ED, Graney B, Baird S, Churney T, Fier K, Korn M, et al. Physical activity and activity space in patients with pulmonary fibrosis not prescribed supplemental oxygen. BMC Pulm Med 2017;17(1):154 [FREE Full text] [doi: 10.1186/s12890-017-0495-2] [Medline: 29169394]

176. Rykov Y, Thach TQ, Dunleavy G, Roberts AC, Christopoulos G, Soh CK, et al. Activity tracker-based metrics as digital markers of cardiometabolic health in working adults: cross-sectional study. JMIR Mhealth Uhealth 2020;8(1):e16409 [FREE Full text] [doi: 10.2196/16409] [Medline: 32012098] 
177. Saarikko J, Niela-Vilen H, Ekholm E, Hamari L, Azimi I, Liljeberg P, et al. Continuous 7-month internet of things-based monitoring of health parameters of pregnant and postpartum women: prospective observational feasibility study. JMIR Form Res 2020;4(7):e12417 [FREE Full text] [doi: 10.2196/12417] [Medline: 32706696]

178. Saif N, Yan P, Niotis K, Scheyer O, Rahman A, Berkowitz M, et al. Feasibility of using a wearable biosensor device in patients at risk for Alzheimer's disease dementia. J Prev Alzheimers Dis 2020;7(2):104-111 [FREE Full text] [doi: 10.14283/jpad.2019.39] [Medline: 32236399]

179. Scarlett S, Nolan H, Kenny RA, O'Connell MD. Objective sleep duration in older adults: results from the Irish longitudinal study on ageing. J Am Geriatr Soc 2020;68(1):120-128. [doi: 10.1111/jgs.16177] [Medline: 31579942]

180. Sehgal S, Chowdhury A, Rabih F, Gadre A, Park MM, Li M, STep-count using an Accelerometer for Monitoring PAH-STAMP Study group. Counting steps: a new way to monitor patients with pulmonary arterial hypertension. Lung 2019;197(4):501-508. [doi: 10.1007/s00408-019-00239-y] [Medline: 31144016]

181. Semaan S, Dewland TA, Tison GH, Nah G, Vittinghoff E, Pletcher MJ, et al. Physical activity and atrial fibrillation: data from wearable fitness trackers. Heart Rhythm 2020;17(5 Pt B):842-846. [doi: 10.1016/j.hrthm.2020.02.013] [Medline: $\underline{32354448]}$

182. Shaw RJ, Barnes A, Steinberg D, Vaughn J, Diane A, Levine E, et al. Enhancing diabetes self-management through collection and visualization of data from multiple mobile health technologies: protocol for a development and feasibility trial. JMIR Res Protoc 2019;8(6):e13517 [FREE Full text] [doi: 10.2196/13517] [Medline: 31162127 ]

183. Shen H, Zhao J, Zhou X, Li J, Wan Q, Huang J, et al. Impaired chronotropic response to physical activities in heart failure patients. BMC Cardiovasc Disord 2017;17(1):136 [FREE Full text] [doi: 10.1186/s12872-017-0571-9] [Medline: 28545575]

184. Shilaih M, Goodale BM, Falco L, Kübler F, De Clerck V, Leeners B. Modern fertility awareness methods: wrist wearables capture the changes in temperature associated with the menstrual cycle. Biosci Rep 2018;38(6):BSR20171279 [FREE Full text] [doi: 10.1042/BSR20171279] [Medline: 29175999]

185. Shilaih M, Clerck V, Falco L, Kübler F, Leeners B. Pulse rate measurement during sleep using wearable sensors, and its correlation with the menstrual cycle phases, a prospective observational study. Sci Rep 2017;7(1):1294 [FREE Full text] [doi: 10.1038/s41598-017-01433-9] [Medline: 28465583]

186. Shufelt CL, Kim A, Joung S, Barsky L, Arnold C, Cheng S, et al. Biometric and psychometric remote monitoring and cardiovascular risk biomarkers in ischemic heart disease. J Am Heart Assoc 2020;9(18):e016023 [FREE Full text] [doi: 10.1161/JAHA.120.016023] [Medline: 32896202]

187. Silverman-Lloyd LG, Kianoush S, Blaha MJ, Sabina AB, Graham GN, Martin SS. mActive-Smoke: a prospective observational study using mobile health tools to assess the association of physical activity with smoking urges. JMIR Mhealth Uhealth 2018;6(5):e121 [FREE Full text] [doi: 10.2196/mhealth.9292] [Medline: 29752250]

188. Smith SL, Ludy MJ, Tucker RM. Changes in taste preference and steps taken after sleep curtailment. Physiol Behav 2016;163:228-233. [doi: 10.1016/j.physbeh.2016.05.002] [Medline: 27184237]

189. Solomon MD, Yang J, Sung SH, Livingston ML, Sarlas G, Lenane JC, et al. Incidence and timing of potentially high-risk arrhythmias detected through long term continuous ambulatory electrocardiographic monitoring. BMC Cardiovasc Disord 2016;16:35 [FREE Full text] [doi: 10.1186/s12872-016-0210-x] [Medline: 26883019]

190. Souza RT, Cecatti JG, Mayrink J, Galvão RB, Costa ML, Feitosa F, MAES-I Study Group. Identification of earlier predictors of pregnancy complications through wearable technologies in a Brazilian multicentre cohort: Maternal Actigraphy Exploratory Study I (MAES-I) study protocol. BMJ Open 2019;9(4):e023101 [FREE Full text] [doi: 10.1136/bmjopen-2018-023101] [Medline: 31005906]

191. Steinhubl SR, Waalen J, Edwards AM, Ariniello LM, Mehta RR, Ebner GS, et al. Effect of a home-based wearable continuous ECG monitoring patch on detection of undiagnosed atrial fibrillation: the mSToPS randomized clinical trial. JAMA 2018;320(2):146-155 [FREE Full text] [doi: 10.1001/jama.2018.8102] [Medline: 29998336]

192. Stelzer EM, Book S, Graessel E, Hofner B, Kornhuber J, Luttenberger K. Bouldering psychotherapy reduces depressive symptoms even when general physical activity is controlled for: a randomized controlled trial. Heliyon 2018;4(3):e00580 [FREE Full text] [doi: 10.1016/j.heliyon.2018.e00580] [Medline: 29862344]

193. Strain T, Wijndaele K, Dempsey PC, Sharp SJ, Pearce M, Jeon J, et al. Wearable-device-measured physical activity and future health risk. Nat Med 2020;26(9):1385-1391. [doi: 10.1038/s41591-020-1012-3] [Medline: 32807930]

194. Tateishi K, Ohtani N, Ohta M. Physiological effects of interactions between female dog owners with neuroticism and their dogs. J Vet Behav 2014;9(6):304-310. [doi: 10.1016/j.jveb.2014.08.005]

195. Thijs I, Fresiello L, Oosterlinck W, Sinnaeve P, Rega F. Assessment of physical activity by wearable technology during rehabilitation after cardiac surgery: explorative prospective monocentric observational cohort study. JMIR Mhealth Uhealth 2019;7(1):e9865 [FREE Full text] [doi: 10.2196/mhealth.9865] [Medline: $\underline{\text { 30702433] }}$

196. Thomas S, Yingling L, Adu-Brimpong J, Mitchell V, Ayers CR, Wallen GR, et al. Mobile health technology can objectively capture physical activity (PA) targets among African-American women within resource-limited communities-the Washington, D.C. cardiovascular health and needs assessment. J Racial Ethn Health Disparities (forthcoming) 2016:- (forthcoming) [FREE Full text] [doi: 10.1007/s40615-016-0290-4] [Medline: 27913983]

197. Thompson JF, Severson RL, Rosecrance JC. Occupational physical activity in brewery and office workers. J Occup Environ Hyg 2018;15(9):686-699. [doi: 10.1080/15459624.2018.1492136] [Medline: $\underline{\text { 30188781] }}$ 
198. Thorup C, Hansen J, Grønkjær M, Andreasen JJ, Nielsen G, Sørensen EE, et al. Cardiac patients' walking activity determined by a step counter in cardiac telerehabilitation: data from the intervention arm of a randomized controlled trial. J Med Internet Res 2016;18(4):e69 [FREE Full text] [doi: 10.2196/jmir.5191] [Medline: 27044310]

199. Tomitani N, Kanegae H, Suzuki Y, Kuwabara M, Kario K. Stress-induced blood pressure elevation self-measured by a wearable watch-type device. Am J Hypertens 2021;34(4):377-382 [FREE Full text] [doi: 10.1093/ajh/hpaa139] [Medline: $\underline{32852527]}$

200. Turakhia MP, Ullal AJ, Hoang DD, Than CT, Miller JD, Friday KJ, et al. Feasibility of extended ambulatory electrocardiogram monitoring to identify silent atrial fibrillation in high-risk patients: the Screening Study for Undiagnosed Atrial Fibrillation (STUDY-AF). Clin Cardiol 2015;38(5):285-292 [FREE Full text] [doi: 10.1002/clc.22387] [Medline: 25873476]

201. Turel O, Romashkin A, Morrison KM. Health outcomes of information system use lifestyles among adolescents: videogame addiction, sleep curtailment and cardio-metabolic deficiencies. PLoS One 2016;11(5):e0154764 [FREE Full text] [doi: 10.1371/journal.pone.0154764] [Medline: 27149512]

202. Twiggs J, Salmon L, Kolos E, Bogue E, Miles B, Roe J. Measurement of physical activity in the pre- and early post-operative period after total knee arthroplasty for osteoarthritis using a Fitbit Flex device. Med Eng Phys 2018;51:31-40. [doi: 10.1016/j.medengphy.2017.10.007] [Medline: 29117912]

203. van der Kamp MR, Thio BJ, Tabak M, Hermens HJ, Driessen J, van der Palen J. Does exercise-induced bronchoconstriction affect physical activity patterns in asthmatic children? J Child Health Care 2020;24(4):577-588. [doi: 10.1177/1367493519881257] [Medline: 31607144]

204. van Wamelen DJ, Hota S, Podlewska A, Leta V, Trivedi D, Rizos A, et al. Non-motor correlates of wrist-worn wearable sensor use in Parkinson's disease: an exploratory analysis. NPJ Parkinsons Dis 2019;5:22 [FREE Full text] [doi: 10.1038/s41531-019-0094-4] [Medline: 31602393]

205. Vaughn NH, Dunklebarger MF, Mason MW. Individual patient-reported activity levels before and after joint arthroplasty are neither accurate nor reproducible. Clin Orthop Relat Res 2019;477(3):536-544 [FREE Full text] [doi: 10.1097/CORR.0000000000000591] [Medline: 30543533]

206. Venkataramanan R, Thirunarayan K, Jaimini U, Kadariya D, Yip HY, Kalra M, et al. Determination of personalized asthma triggers from multimodal sensing and a mobile app: observational study. JMIR Pediatr Parent 2019;2(1):e14300 [FREE Full text] [doi: 10.2196/14300] [Medline: 31518318]

207. Wallace M, Downing N, Lourens S, Mills J, Kim JI, Long J, Predict-Hd Investigators And Coordinators Of The Huntington Study Group. Is there an association of physical activity with brain volume, behavior, and day-to-day functioning? A cross sectional design in prodromal and early Huntington disease. PLoS Curr 2016;8:ecurrents.hd.cba6ea74972cf8412a73ce52eb018c1e [FREE Full text] [doi: 10.1371/currents.hd.cba6ea74972cf8412a73ce52eb018c1e] [Medline: 27818843]

208. Wang C, Lizardo O, Hachen DS. Using Fitbit data to monitor the heart rate evolution patterns of college students. J Am Coll Health 2020:1-8. [doi: 10.1080/07448481.2020.1775610] [Medline: $\underline{\text { 32569509] }}$

209. Weatherall J, Paprocki Y, Meyer TM, Kudel I, Witt EA. Sleep tracking and exercise in patients with type 2 diabetes mellitus (Step-D): pilot study to determine correlations between Fitbit data and patient-reported outcomes. JMIR Mhealth Uhealth 2018;6(6):e131 [FREE Full text] [doi: 10.2196/mhealth.8122] [Medline: 29871856]

210. Weeks DL, Sprint GL, Stilwill V, Meisen-Vehrs AL, Cook DJ. Implementing wearable sensors for continuous assessment of daytime heart rate response in inpatient rehabilitation. Telemed J E Health 2018;24(12):1014-1020 [FREE Full text] [doi: 10.1089/tmj.2017.0306] [Medline: 29608421]

211. Wiles T, Kellogg D, Furr H, Nessler JA, Newcomer SC. Characterization of adult heart rate responses during recreational skateboarding at community skateparks. Int J Exerc Sci 2020;13(2):501-510 [FREE Full text] [Medline: 32509111]

212. Winnebeck EC, Fischer D, Leise T, Roenneberg T. Dynamics and ultradian structure of human sleep in real life. Curr Biol 2018;28(1):49-59.e5 [FREE Full text] [doi: 10.1016/j.cub.2017.11.063] [Medline: 29290561]

213. Wyatt KD, Poole LR, Mullan AF, Kopecky SL, Heaton HA. Clinical evaluation and diagnostic yield following evaluation of abnormal pulse detected using Apple watch. J Am Med Inform Assoc 2020;27(9):1359-1363 [FREE Full text] [doi: 10.1093/jamia/ocaa137] [Medline: 32979046]

214. Xu X, Conomos MP, Manor O, Rohwer JE, Magis AT, Lovejoy JC. Habitual sleep duration and sleep duration variation are independently associated with body mass index. Int J Obes (Lond) 2018;42(4):794-800. [doi: 10.1038/ijo.2017.223] [Medline: 28895585]

215. Yang Y, Hirdes JP, Dubin JA, Lee J. Fall risk classification in community-dwelling older adults using a smart wrist-worn device and the resident assessment instrument-home care: prospective observational study. JMIR Aging 2019;2(1):e12153 [FREE Full text] [doi: 10.2196/12153] [Medline: $\underline{31518278]}$

216. Youn IH, Lee JM. Seafarers' physical activity and sleep patterns: results from Asia-Pacific sea routes. Int J Environ Res Public Health 2020;17(19):7266 [FREE Full text] [doi: 10.3390/ijerph17197266] [Medline: 33027892]

217. Yu Y, Chen Z, Bu J, Zhang Q. Do stairs inhibit seniors who live on upper floors from going out? HERD 2020;13(4):128-143. [doi: 10.1177/1937586720936588] [Medline: 32666833] 
218. Zhu G, Catt M, Cassidy S, Birch-Machin M, Trenell M, Hiden H, et al. Objective sleep assessment in $>80,000$ UK mid-life adults: associations with sociodemographic characteristics, physical activity and caffeine. PLoS One 2019;14(12):e0226220 [FREE Full text] [doi: 10.1371/journal.pone.0226220] [Medline: $\underline{31881028}$ ]

219. Zhuo K, Gao C, Wang X, Zhang C, Wang Z. Stress and sleep: a survey based on wearable sleep trackers among medical and nursing staff in Wuhan during the COVID-19 pandemic. Gen Psychiatr 2020;33(3):e100260 [FREE Full text] [doi: 10.1136/gpsych-2020-100260] [Medline: 32596641]

220. Page MJ, McKenzie JE, Bossuyt PM, Boutron I, Hoffmann TC, Mulrow CD, et al. The PRISMA 2020 statement: an updated guideline for reporting systematic reviews. Syst Rev 2021;10(1):89 [FREE Full text] [doi: 10.1186/s13643-021-01626-4] [Medline: $\underline{33781348]}$

221. Create your own custom map. MapChart. URL: https://mapchart.net/ [accessed 2022-01-19]

222. Allen J. Photoplethysmography and its application in clinical physiological measurement. Physiol Meas 2007;28(3):R1-39. [doi: 10.1088/0967-3334/28/3/R01] [Medline: 17322588]

223. Gandomi A, Haider M. Beyond the hype: big data concepts, methods, and analytics. Int J Inf Manage 2015;35(2):137-144. [doi: 10.1016/j.ijinfomgt.2014.10.007]

224. Wright SP, Hall Brown TS, Collier SR, Sandberg K. How consumer physical activity monitors could transform human physiology research. Am J Physiol Regul Integr Comp Physiol 2017;312(3):R358-R367. [doi: 10.1152/ajpregu.00349.2016] [Medline: 28052867]

225. Kristoffersson A, Lindén M. A systematic review on the use of wearable body sensors for health monitoring: a qualitative synthesis. Sensors (Basel) 2020;20(5):15902 [FREE Full text] [doi: 10.3390/s20051502] [Medline: 32182907]

226. Nelson BW, Low CA, Jacobson N, Areán P, Torous J, Allen NB. Guidelines for wrist-worn consumer wearable assessment of heart rate in biobehavioral research. NPJ Digit Med 2020;3:90 [FREE Full text] [doi: 10.1038/s41746-020-0297-4] [Medline: 32613085]

227. Who are the world's biggest wearable tech buyers? Ipsos. 2018. URL: https://www.ipsos.com/en-ro/ who-are-worlds-biggest-wearable-tech-buyers [accessed 2021-05-20]

228. Vailshery LS. Number of connected wearable devices worldwide by region from 2015 to 2022. Statista. 2021. URL: https:/ /www.statista.com/statistics/490231/wearable-devices-worldwide-by-region/ [accessed 2021-05-20]

229. What is GDPR, the EU's new data protection law? General Data Protection Regulation.: European Union; 2018. URL: https://gdpr.eu/what-is-gdpr/ [accessed 2021-06-08]

230. Blankertz A, Specht L. On regulation for data trusts: policy brief. Stiftung Neue Verantwortung. 2021. URL: https://www. stiftung-nv.de/en/publication/regulation-data-trusts [accessed 2021-07-06]

231. Populations underrepresented in the extramural scientific workforce. Scientific Workforce Diversity.: National Institutes of Health; 2020. URL: https://diversity.nih.gov/about-us/population-underrepresented [accessed 2021-10-13]

232. Evans GF, Shirk A, Muturi P, Soliman EZ. Feasibility of using mobile ECG recording technology to detect atrial fibrillation in low-resource settings. Glob Heart 2017;12(4):285-289. [doi: 10.1016/j.gheart.2016.12.003] [Medline: 28302547]

233. Hicks JL, Althoff T, Sosic R, Kuhar P, Bostjancic B, King AC, et al. Best practices for analyzing large-scale health data from wearables and smartphone apps. NPJ Digit Med 2019;2:45 [FREE Full text] [doi: 10.1038/s41746-019-0121-1] [Medline: 31304391]

234. Xu S, Rwei AY, Vwalika B, Chisembele MP, Stringer JS, Ginsburg AS, et al. Wireless skin sensors for physiological monitoring of infants in low-income and middle-income countries. Lancet Digit Health 2021;3(4):e266-e273 [FREE Full text] [doi: 10.1016/S2589-7500(21)00001-7] [Medline: 33640306]

235. Sauerborn R. A gaping research gap regarding the climate change impact on health in poor countries. Eur J Epidemiol 2017;32(9):855-856 [FREE Full text] [doi: 10.1007/s10654-017-0258-7] [Medline: 28573342]

236. Barteit S, Boudo V, Ouedraogo A, Zabré P, Ouremi L, Sié A, et al. Feasibility, acceptability and validation of wearable devices for climate change and health research in the low-resource contexts of Burkina Faso and Kenya: study protocol. PLoS One 2021;16(9):e0257170 [FREE Full text] [doi: 10.1371/journal.pone.0257170] [Medline: $\underline{34591893]}$

237. Lam CK, Hang J, Zhang D, Wang Q, Ren M, Huang C. Effects of short-term physiological and psychological adaptation on summer thermal comfort of outdoor exercising people in China. Build Environ 2021;198:107877. [doi: 10.1016/j.buildenv.2021.107877]

\section{Abbreviations}

AF: atrial fibrillation

API: application programing interface

CE: Communauté Européenne

ECG: electrocardiogram

FDA: Food and Drug Administration

HR: heart rate

PA: physical activity

PRISMA: Preferred Reporting Items for Systematic Reviews and Meta-Analyses 
PRISMA-ScR: Preferred Reporting Items for Systematic Reviews and Meta-Analyses extension for Scoping Reviews

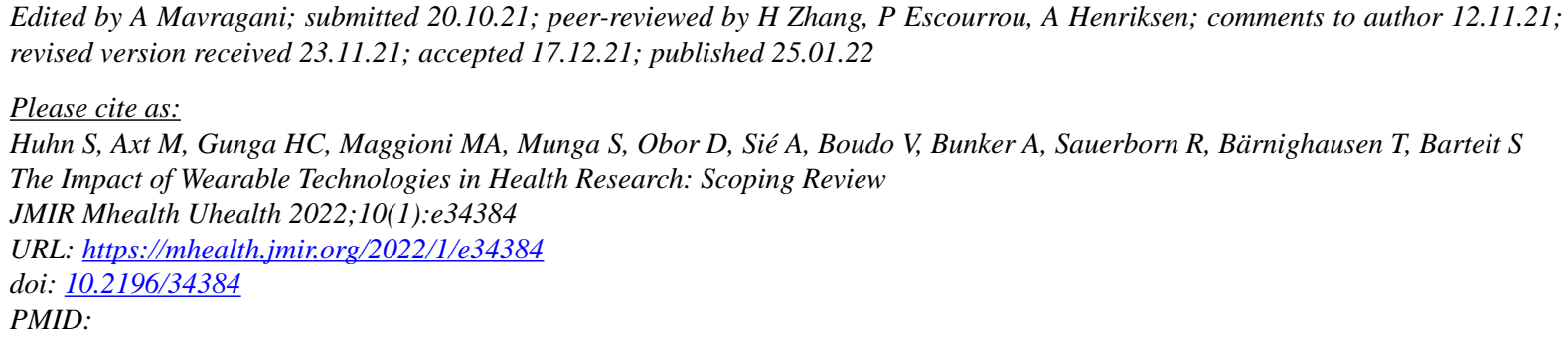

(CSophie Huhn, Miriam Axt, Hanns-Christian Gunga, Martina Anna Maggioni, Stephen Munga, David Obor, Ali Sié, Valentin Boudo, Aditi Bunker, Rainer Sauerborn, Till Bärnighausen, Sandra Barteit. Originally published in JMIR mHealth and uHealth (https://mhealth.jmir.org), 25.01.2022. This is an open-access article distributed under the terms of the Creative Commons Attribution License (https://creativecommons.org/licenses/by/4.0/), which permits unrestricted use, distribution, and reproduction in any medium, provided the original work, first published in JMIR mHealth and uHealth, is properly cited. The complete bibliographic information, a link to the original publication on https://mhealth.jmir.org/, as well as this copyright and license information must be included. 